\title{
Il disegno e la costruzione dello spazio di vita e delle relazioni. La Boca di Buenos Aires e lo spazio di Benito Quinquela Martín
}

\author{
Rosario Marrocco
}

Abstract

Questo contributo presenta uno studio sul disegno dello spazio di vita del barrio de La Boca di Buenos Aires attraverso le rappresentazioni di Benito Quinquela Martín. Rappresentazioni di grande intensità espressiva e spaziale che condensano il dramma e la speranza della grande immigrazione in Sudamerica. Un costante riferimento al rapporto tra uomo e spazio come connessione continua di spazialità architettoniche e sociali, antropologiche e culturali. Disegni che convertono la realtà di un vissuto povero in contrastanti visioni futuristiche alternate a istanze emotive e riflessive, dove la dignità del trabajo appare una costante straziante e tormentata, espressione e fondamento della connessione tra gli uomini e lo spazio. Nelle rappresentazioni di B.Q.M., che sono grandi tessuti di connessione tra l'umano e lo spaziale, appare la vita costruita sulle azioni umane e confusa tra fumi, tiranti, vele e prue di barche. Frutto dell'immigrazione giunta a Sud del continente americano, lo spazio de La Boca, nonostante la vitalità urbana e spaziale indotta dal turismo, dalla municipalità e dalle trasformazioni sociali, è ancora poggiato su quelle rappresentazioni. I colori e le conversioni industriali e portuali ancora circondano un mondo fatto di provvisorietà dove le uniche certezze sembrano essere quelle delle relazioni - oggi certamente diverse - tra gli uomini e tra gli uomini e lo spazio. Uno spazio di vita periferico, instancabile e reversibile, tumultuoso e calviniano, dove tutto sembra scomporsi e ricomporsi attraverso un disegno incessante dello spazio di vita.

Parole chiave

disegno dello spazio di vita, disegno dello spazio delle relazioni, La Boca Buenos Aires, Benito Quinquela Martín, John Berger.

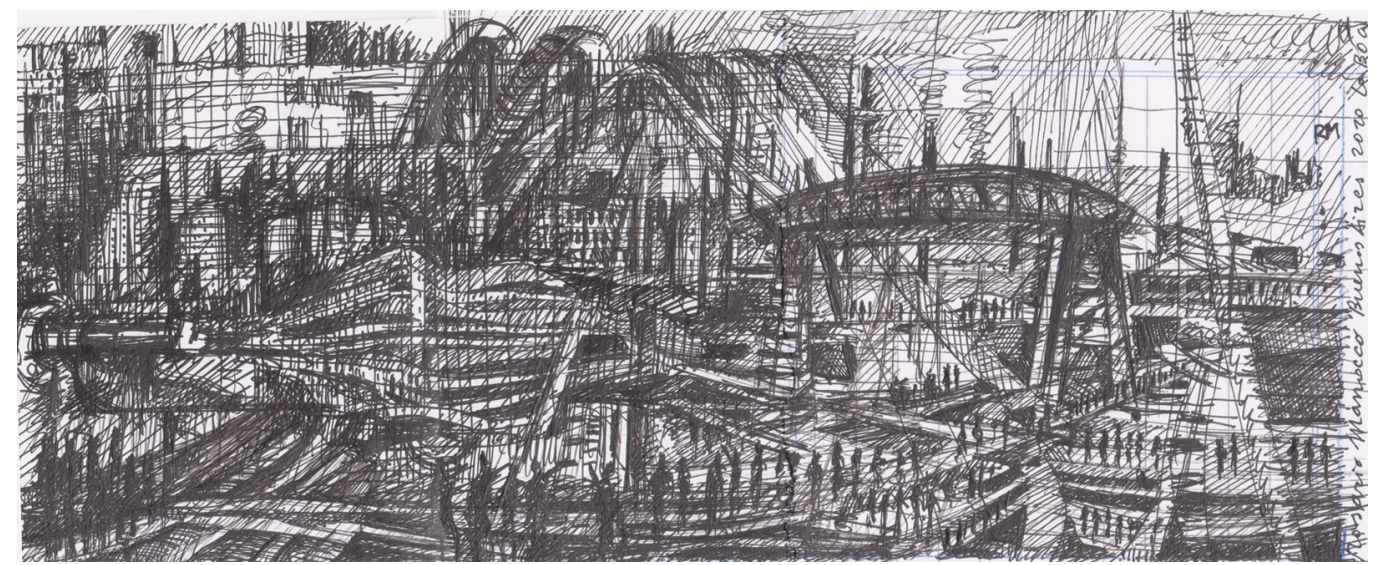


"Si guardano sempre i dipinti nella speranza di scoprire un segreto. Non un segreto sull'arte, ma sulla vita. E se si scopre, rimarrà un segreto perché, dopo tutto, non può essere tradotto in parole. Con le parole, l'unica cosa che è possibile fare è disegnare, a grandi linee, una mappa che ci guida verso di esso"

[Berger 2015, p. 59].

"Se dovessi racchiudere in una sola parola la tensione profonda che segna il lavoro di Berger sceglierei un verbo: "connettere'" [I]. Connettere tutto ciò che risulta frammentato, separato. Tutto quello che si stratifica nel tempo, per parti, per frammenti. Spazi, identità, uomini. Connettere spazi e uomini attraverso un segno e un'identità comune, connetterli attraverso una rappresentazione. Questo avviene spesso nelle arti, nella letteratura, nei romanzi, nelle narrazioni cinematografiche, nelle pitture, e quando tentiamo di trovare questa connessione tra le cose, alla fine scopriamo sempre le relazioni tra gli uomini, le relazioni tra gli spazi e le relazioni tra l'uomo e lo spazio, che rivelano lo spazio di vita e dell'abitare. Scopriamo le manifestazioni della vita perché il vivere non è altro che una continua connessione tra le cose, che ha un inizio e una fine.

Riguardo Berger, riguardo l'intera opera di Berger - anche quella dedicata al disegno [Berger 20 I I] e quella dedicata alla lettura critica di una certa realtà politica [2] - effettivamente questa è rivolta alla ricerca delle connessioni, delle identità e delle verità. É rivolta alla ricerca delle relazioni, tra l'osservare il mondo dall'esterno e il vederlo essendone una parte, tra il rappresentarlo e lo starci dentro. D'altro canto, se la ricerca della connessione tra uomo e spazio è una priorità per la vita dell'uomo e per la stessa vita dello spazio - sia esso fisico o mentale - gran parte delle rappresentazioni, in un modo o in un altro, non soltanto esprimono la ricerca di questa condizione necessaria per la sopravvivenza, ma anche la determinano, fissandola nella rappresentazione. I disegni rappresentano la connessione tra gli spazi e gli uomini e spesso contengono quei segreti sulla vita e sull'esistenza di fronte ai

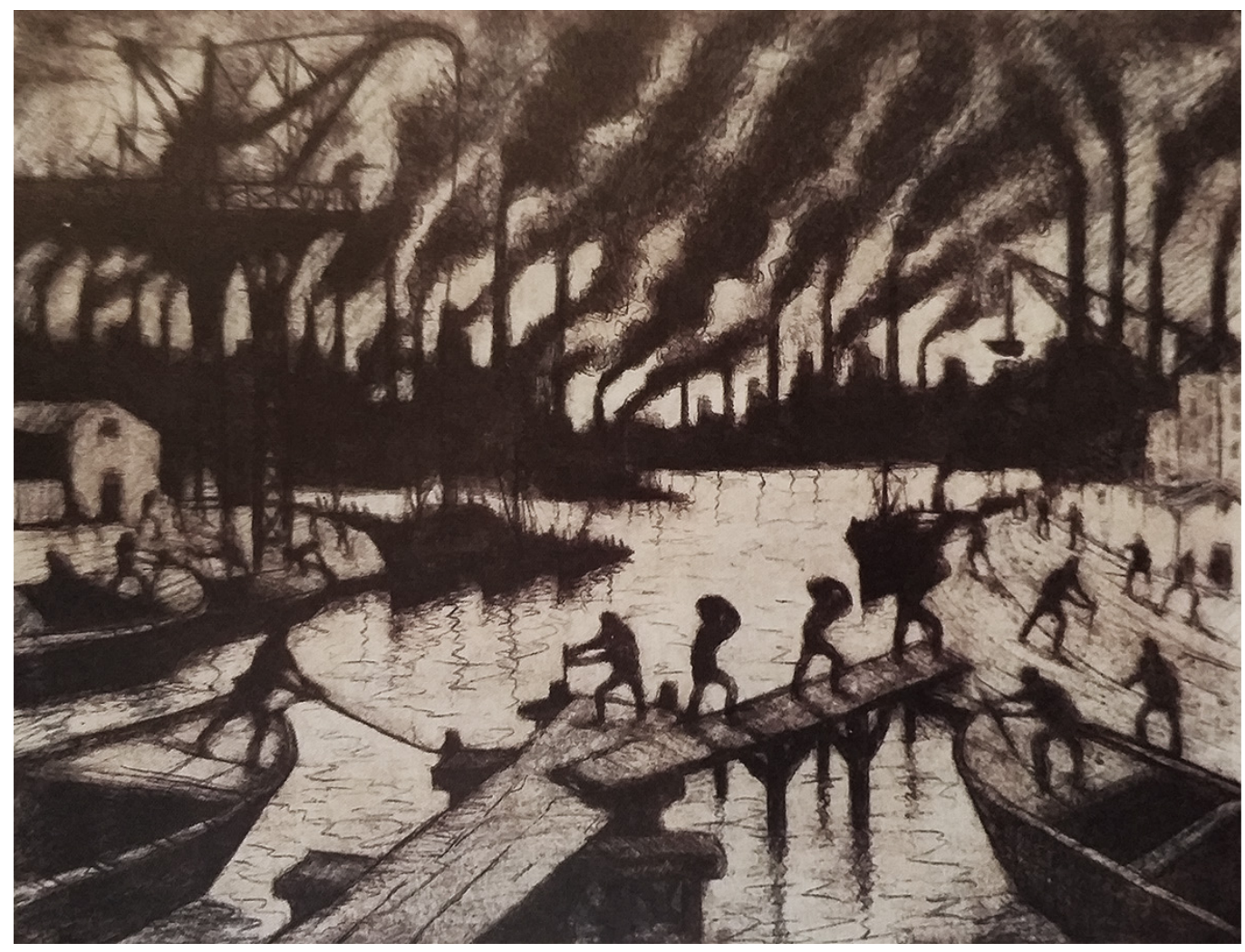




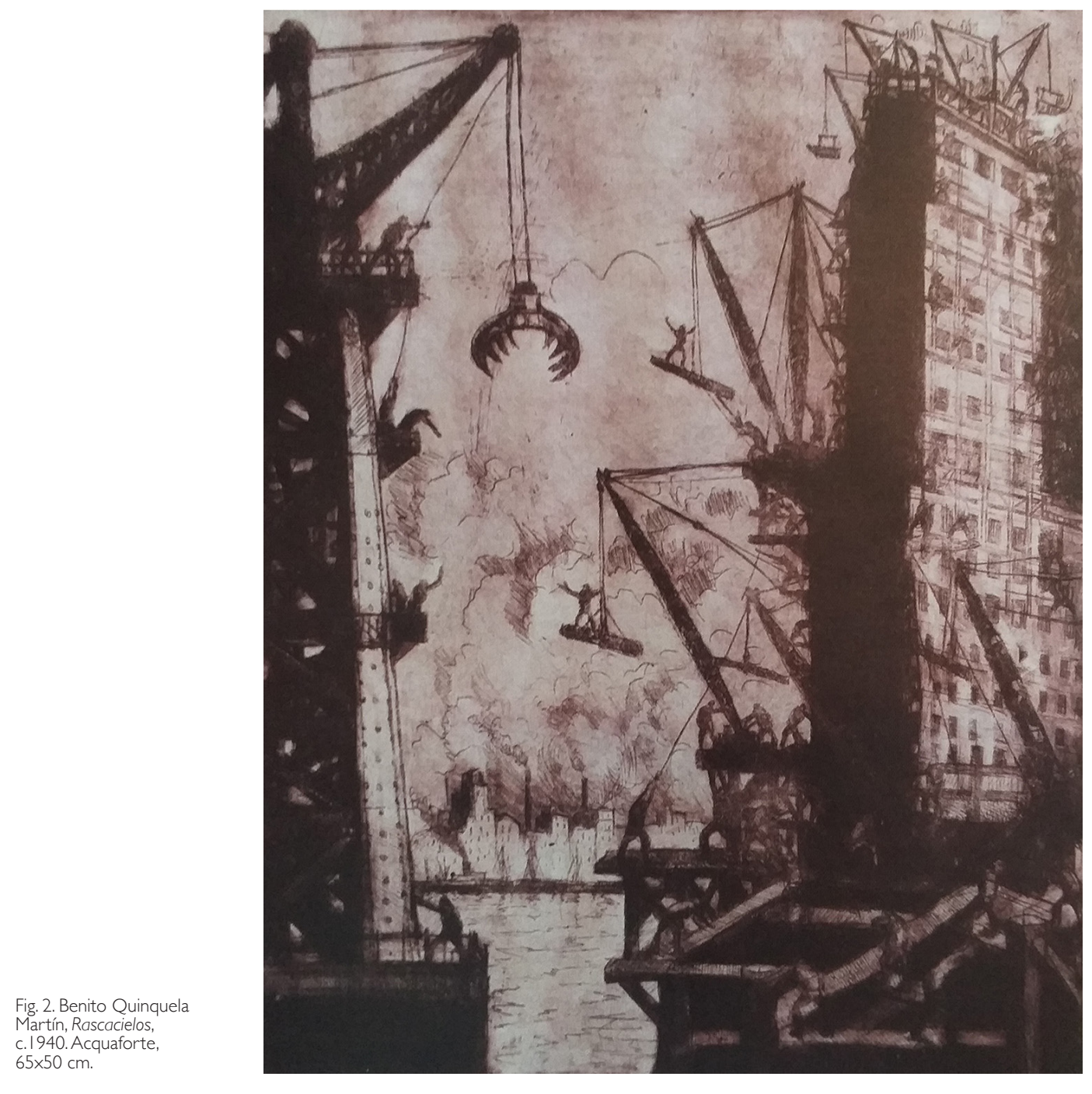

quali, tuttavia, a volte rimangono delle profonde incertezze. Come scrive Berger, quei segreti si cercano guardando un disegno. Talvolta sembrano emergere ma poi, inevitabilmente, si riannodano nelle parole che tentano di rivelarli e raccontarli, perché alla fine, dopotutto, le parole possono soltanto tracciare delle direzioni rispetto a quei segreti contenuti nei disegni e nelle rappresentazioni, e delle interpretazioni rispetto a quei modi di vedere e costruire il mondo.

La figura e il lavoro di Benito Quinquela Martín [3] rappresentano in questo contesto un caso emblematico per il costante riferimento al rapporto tra uomo e spazio come connessione continua di spazialità architettoniche e sociali, antropologiche e culturali. Spazialità rappresentate dal suo mondo, dal suo spazio fisico, affacciato sul Riachuelo, e dal suo spazio mentale. Rappresentazioni di grande intensità espressiva e spaziale che riassumono e condensano il dramma e la speranza della grande immigrazione in Sudamerica. Disegni e rappresentazioni che convertono la realtà di un vissuto povero in contrastanti visioni futuristiche alternate a istanze emotive e riflessive, dove la dignità del trabajo appare una costante straziante e tormentata, espressione e fondamento della connessione tra gli uomini e lo spazio. Basti osservare le cinque acqueforti realizzate intorno al 1940 (figg. I-5) per comprendere la necessità di Quinquela Martín di trovare, costruire e rappresentare la connessione con il mondo e la relazione con quello spazio disegnato sempre attraverso grandi e macchinose scenografie che sembrano rievocare gli scenari cinematografici tedeschi e americani dei vari Asphalt, Der letzte Mann o Just Imagine [4]. Di volta in volta in queste 


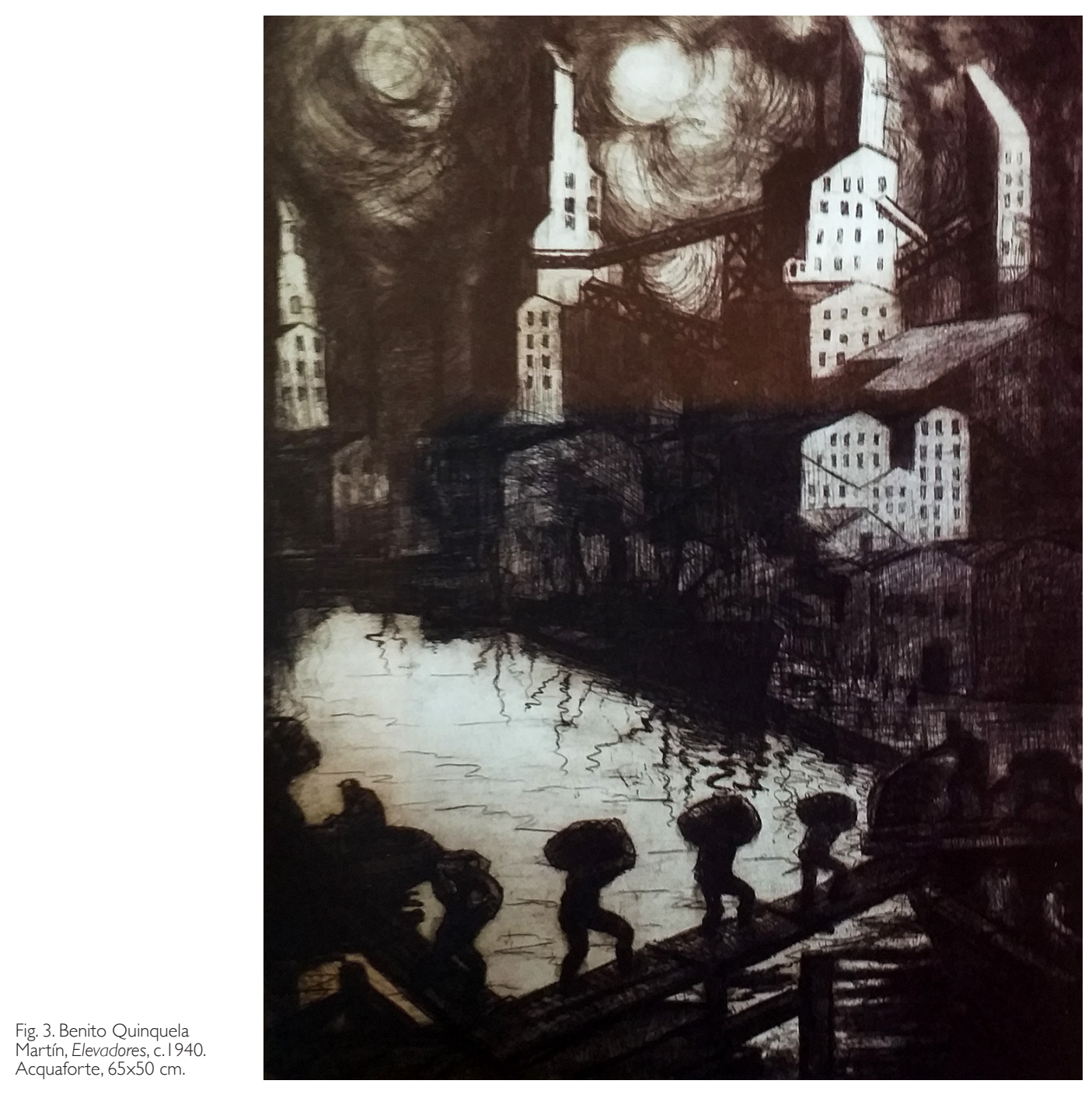

rappresentazioni, che sono come dei grandi tessuti di connessione tra l'umano e lo spaziale, appare la vita (fig. 6) e, confuso tra fumi, tiranti, vele e prue di barche, anche quel segreto della vita, costruita, pezzo per pezzo, sulle azioni umane. Un segreto che si dipana e che si rappresenta attraverso una realtà fredda e cruda, ritratta in modo ossessivo, impressa ed espressa in ogni dettaglio simbolico ma allo stesso tempo didascalico ed elementare, il cui significato ricade e coincide con la volontà dell'appropriazione prorompente dello spazio. Una precisa volontà condotta, con sicurezza, attraverso il controllo della relazione con lo spazio e delle varie mutazioni spaziali, ma anche attraverso la ricerca delle relazioni umane, tra uomo e uomo, dei valori della collettività e della vita in comune.

Al di là della sua vita - Quinquela Martín fu adottato da un genovese e da un'indigena - il substrato della sua opera va ricercato proprio in quel grande spazio storico [5]: La Boca, situato a Sud-Est di Buenos Aires. II barrio fu creato da quegli immigranti, prevalentemente italiani, molti dei quali provenienti da Genova, che innalzarono il loro spazio di vita riproducendo valori spaziali e dimensioni umane, proprio in quel luogo vuoto, ostile e paludoso, con inondazioni periodiche e popolato soltanto di baracche.

II 9 febbraio del 1889 il quotidiano argentino La Nacion riportava La aventura de los inmigrantes: "El vapor italiano Independente fue sometido a una observación sanitaria. Los Inmigrantes se incuentran en el lazareto de Martín García" [6]. Parte di questa imponente immigrazione si distese sul bordo del Riachuelo, particolarmente sulla bocca (da cui, in spagnolo, Boca), dove le sue acque sfociano nel Río de la Plata. Un paesaggio portuale, per molti anni 


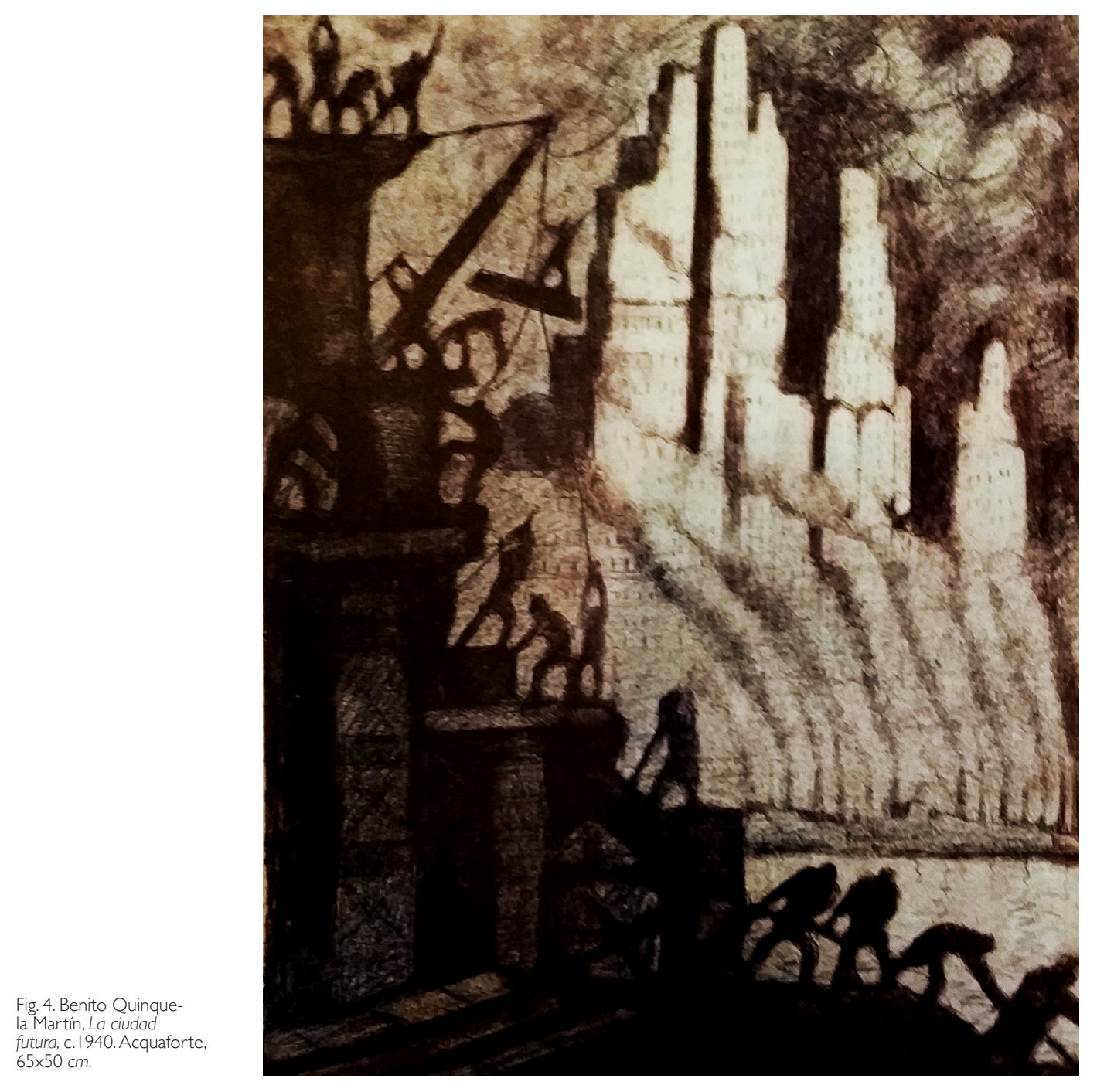

porto naturale di Buenos Aires [7], denso di verticalità visive e sonore appoggiate e incastrate sull'orizzonte grigio-marrone del Río, spesso esaltato cromaticamente da Quinquela Martín (fig. 7). Un reboante frastuono di cose pesanti appoggiate sull'acqua e veicolate su tavole di legno, attraverso funi, carrucole e reti (figg. I, 4). Ogni giorno "de ese puerto era un movimento incesante de barcos; un obrar de talleres, de frigoríficos, de fundiciones; un cargar y descargar de cajones de cereales, de frutas, de carbón; un barullo de gritos, golpes de martillos, sirena de barcos; una vista de grúas, proas, mástiles y cientos de hombres trabajando" [Adamo, Grau 2009, p. 8]. Uno spazio in continua costruzione, dove l'uomo, oltre a costruire, diventa parte della costruzione, perché ogni costruzione porta i segni esasperati di un'umanità che cerca freneticamente la sua identità proprio nello spazio.

La relazione tra gli uomini e tra gli uomini e lo spazio, rappresentata da Quinquela Martín, diventava elemento determinante per vivere e abitare. "Toda la gente que vivía allí había llegado de Italia y se ayudaban unos a otros, porque sabían que compartiendo lo que tenían y lo que no tenían las tristezas serían menos tristes y las alegrías tendrían más sabor" [Adamo, Grau 2009, p. 8]. Così, lo spazio si costruiva su forme di convivenza spontanea e popolare, creando: los conventillos [8], attraverso l'utilizzazione di materiali colorati ricavati da barche e casse di trasporto di legno, ferro e zinco. I conventillos riprendevano le forme spontanee del vivere, tipiche dei popoli del mediterraneo, con l'inserimento di tecniche costruttive portuarie che inventavano, man mano, case elevate sopra pilastri attraverso una sovrapposizione di semplici volumi di legno e zinco ricoperto di pigmenti d'olio tipici delle imbarcazioni. Questi 


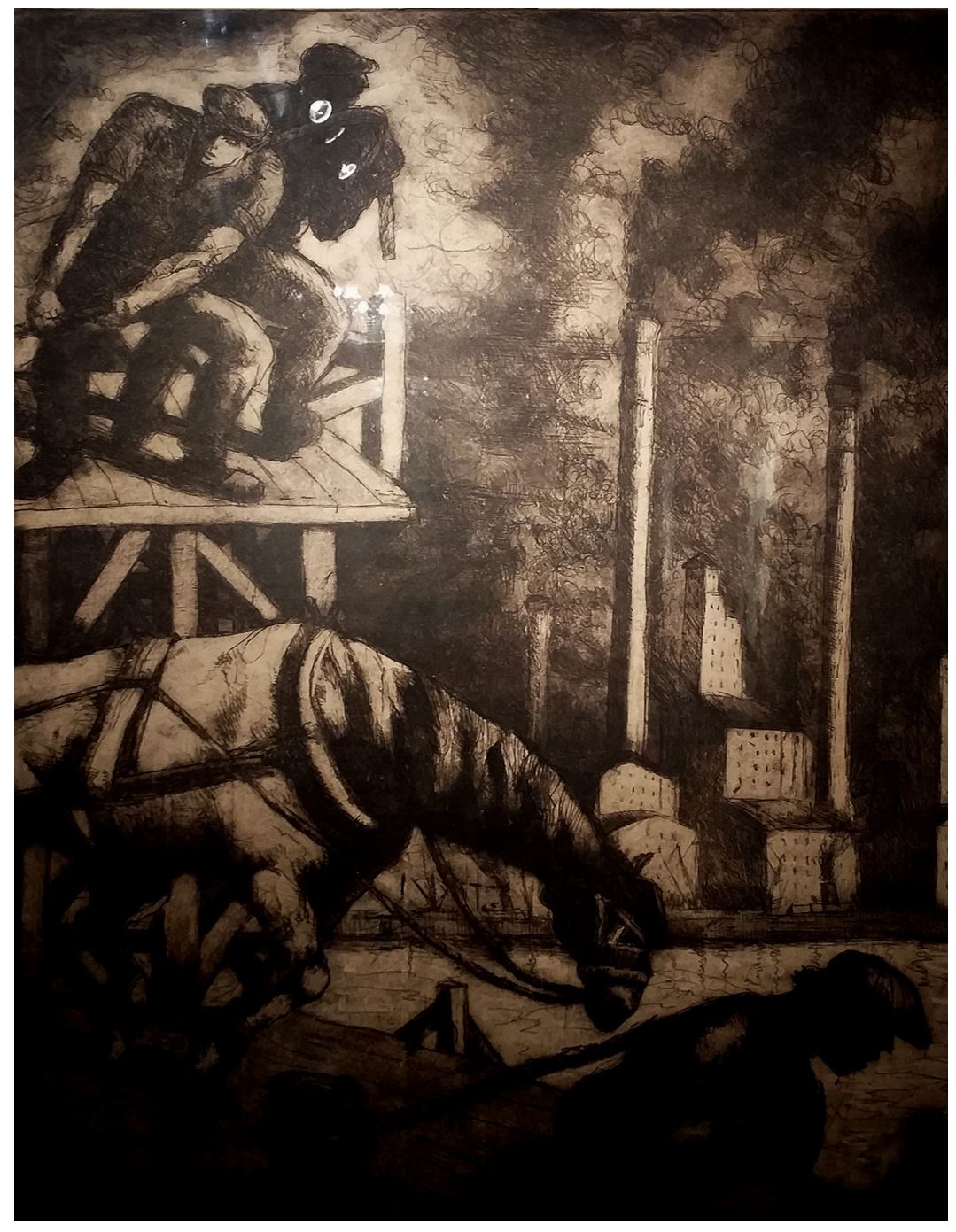

spazi "de madera y zinc", nel diventare case conservavano l'identità, la forma e la materia di quelle barche galleggianti ancorate sul porto come luoghi di passaggio tra il vecchio e il nuovo mondo (fig. 8). Spazi temporanei, spazi di transizione, appoggiati sul Río marrone e collocati dentro un paesaggio grigio e nero di carbone, nero più nero "de las bolsas de carbón" [Adamo, Grau 2009, p. 8]. I disegni e le immagini di questo spazio rappresentano le relazioni umane basate sul linguaggio sociale e sull'abitare in collettività. Rappresentano una rete spontanea di connessioni tra uomo e spazio, tra l'uomo e il paesaggio in cui si ri-trova. Una straordinaria narrazione del poter abitare e del saper abitare lo spazio, traendo da questo tutte le componenti naturali e artificiali che presenta e riconvertendole nella propria esistenza.

Quando il fotografo Horacio Coppola, nel 1931, riprende nel suo scatto il Riachuelo, Puente Almirante Brown (fig. 9), il paesaggio che ritrae è esattamente quello disegnato da Quinquela Martín, appesantito dal marrone della gelatina de plata: acqua, riflessi, funi, ferro e ciminiere, con lo sfondo dell'orma imponente del Puente Transbordador Nicolás Avellaneda inaugurato nel 1914. Un paesaggio che ancora oggi, a distanza di novant'anni, rimane indelebile nonostante i pesanti interventi urbani delle viviendas degli anni Settanta e Ottanta (figg. I0-12). Gli spazi di vita domestici, dentro quel paesaggio, accoglievano famiglie intere che condividevano la cucina, in alto, e il bagno, in basso. II nucleo centrale interno era un patio che funzionava come il cuore dello spazio di vita, amplificato "y delimitados por galerías 


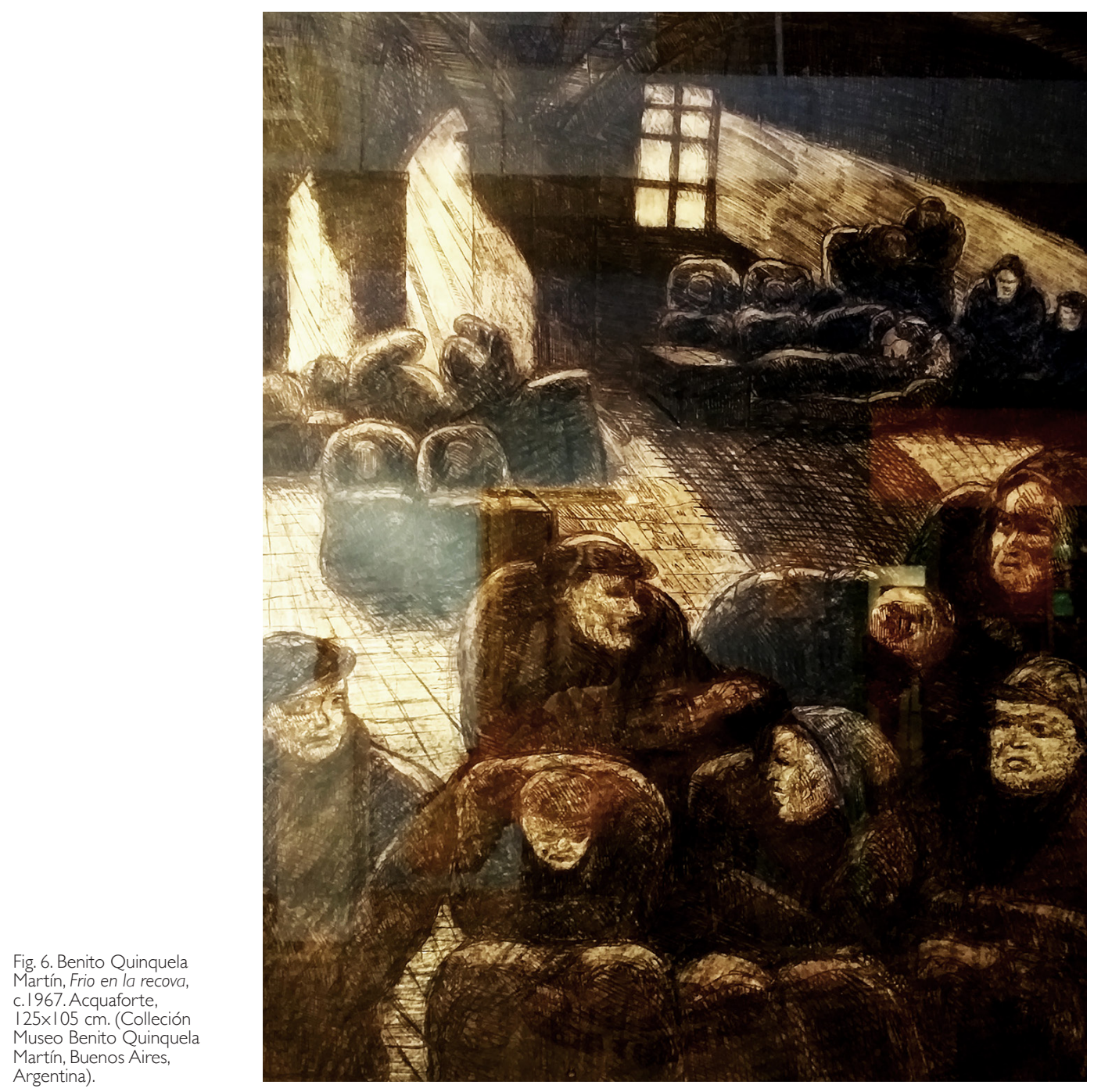

abiertas y conectadas desde la planta baja hasta la planta alta mediante escaleras de madera, frequentemente de dos tramos y notablemente empinadas" [9]. Le scale ripide, quasi come le risalite sulle corde nelle navi, appartengono a quella metafora di collegamento, di connessione tra spazi, tra cose e tra persone. La vita si rappresenta come una finzione scenica, dal tratto teatrale, come prowvisorio, perché nella realtà povera e concreta di un barrio di immigranti, i veri segreti della vita da nascondere sono l'instabilità, la provvisorietà e la precarietà. Per questo, e a fronte di tutto questo, l'uomo cerca la stabilità nelle relazioni umane e con il mondo, quello esterno, quello fluttuante, scuro e fatto d'acqua, quello portuale del Riachuelo.

Nonostante la vitalità urbana e spaziale indotta dal turismo, dalla municipalità e dalle trasformazioni sociali, lo spazio de La Boca è ancora poggiato su queste rappresentazioni e sulle infinite sequenze scenografiche. I colori e le conversioni industriali e portuali ancora circondano un mondo fatto di provvisorietà, dove le uniche certezze sembrano dawvero essere quelle delle relazioni - oggi certamente diverse - tra gli uomini e tra gli uomini e lo spazio. Prowisorietà e certezze che si rivelano nello spazio, che formano lo spazio. Uno spazio di vita periferico, instancabile e reversibile, tumultuoso e calviniano, perché tutto sembra scomporsi e ricomporsi e tutto "invece d'elevarsi sopra, sta appeso sotto: scale di corda, amache, case fatte a sacco, attaccapanni, terrazzi come navicelle, otri d'acqua, becchi del gas, girarrosti, cesti appesi a spaghi, montacarichi, docce, trapezi e anelli per i giochi, tele- 
feriche, lampadari, vasi con piante dal fogliame pendulo" [Calvino 20 I 6, p. I08]. Uno spazio di vita rappresentato nei disegni e nelle pitture di Quinquela Martín e negli scatti fotografici di Coppola, così come, allo stesso modo, è rappresentato sui muri del barrio, sui volti delle persone e sulle loro maglie, nelle prospettive delle gallerie e delle corti ancora visibili, nella comida improwisata e nelle sonorità, incessanti e continue, composte dai suoni e dalle parole che danno forma all'aria. Tutto è un incredibile disegno di uno spazio di vita e di una vita costantemente vissuta nello spazio. Tutto è una grande e reale rappresentazione di relazioni. "A partire dalla convivenza e dalla comunicazione nel patio del conventillo, l'abitante de La Boca disegnò la sua coscienza sociale con un forte accento alla solidarietà, attitudine provocata dal dominio operaio della famiglia, dalla domanda elevata rispetto alla mancanza di servizi e dall'affollamento e dalla condizione di igiene dei luoghi. Così, queste precarie condizione di vita si compensarono con una coscienza e una solidarietà fraterna" [ I 0]. Nella piena libertà compositiva e costruttiva, il disegno de La Boca "se caracterizó por la ausencia de todo tipo de regulacíon que afectara esta generación espontánea de las viviendas, de manera que no existió ningún criterio de orden compositivo ni tampoco una fijación de alineaciones para las fachadas y las alturas de las casas. Así fue que la voluntad de dotar a Buenos Aires de una aparencia ordenada, no encontró lugar este barrio" [ I I ]. Un immenso disegno in progress delle capacità umane di connettere, tessere e costruire un certo mondo.

Fig. 7. Benito Quinquela Martín, Los dos amigos 1960. Olio su tavola, $121 \times 121 \mathrm{~cm}$. (Colleción Museo Benito Quinquela Martín, Buenos Aires,

Argentina)

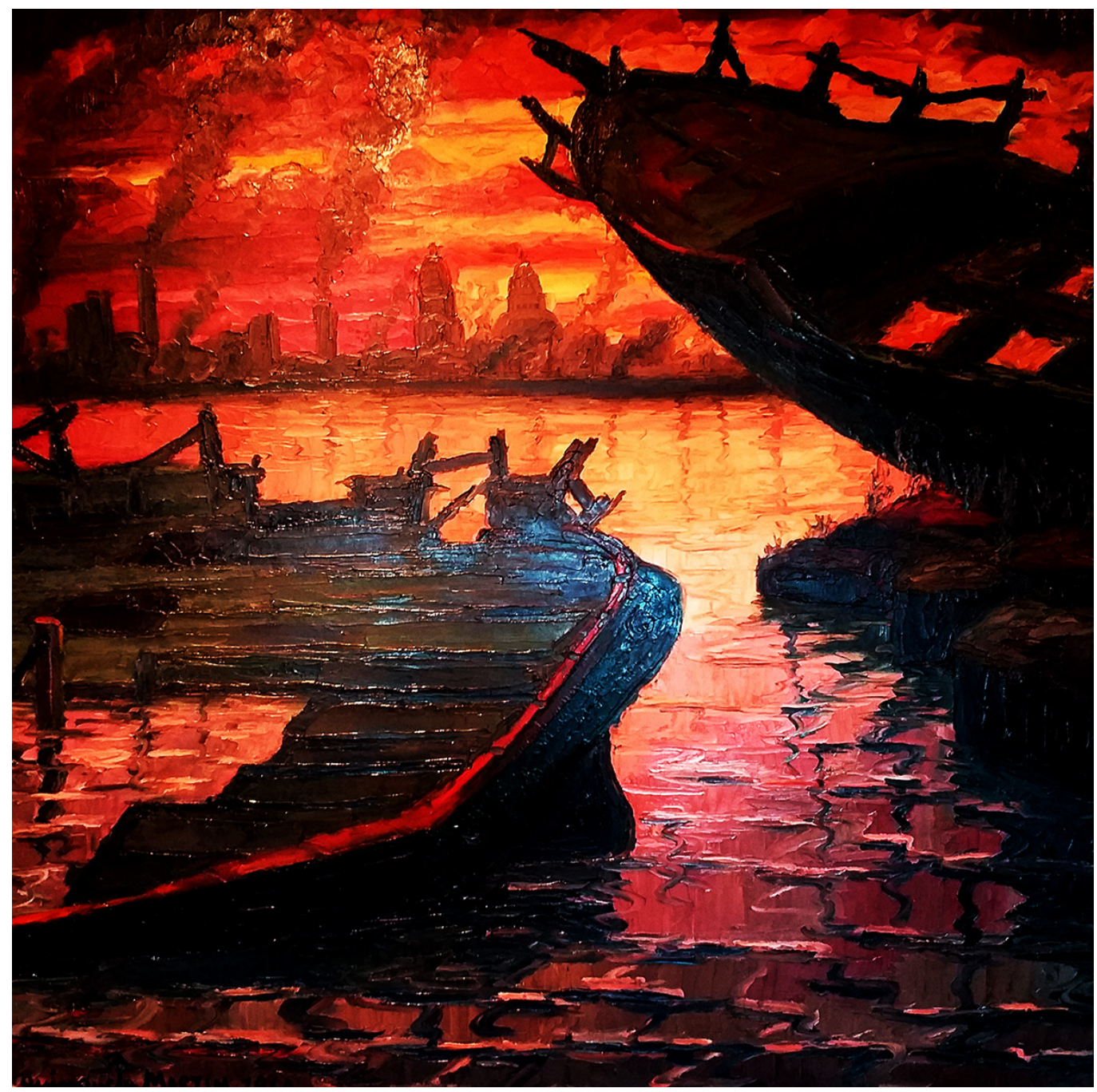


Tornando al pensiero iniziale di Berger, il segreto della rappresentazione sembra qui coincidere con il rappresentato: la vita è il segreto rivelato nella vita rappresentata. Al di là di ogni valore estetico, questi disegni (figg. I-5, 7,9) rappresentano anche il valore sociale dello spazio attraverso il ritorno a quella basilare condizione umana dove il lavorare, il produrre e l'agire definiscono le ragioni sociali dell'esistenza umana nello spazio e sostengono la permanenza sulla terra attraverso la capacità morale umana di esistere e di lavorare eticamente. In questo rapporto tra uomo e spazio anche il tempo, come misura della vita, diventa un fenomeno essenziale che corrisponde alla velocità dell'agire in uno spazio organico, pulsante e vivente. Uno spazio fisico, contenitore di connessioni e relazioni, attraversato da visioni e percezioni umane e immateriali che lo convertono in uno spazio mentale. II bisogno e la necessità di creare lo spazio di vita attraverso la vita nello spazio, spesso si confronta e si contrappone con l'opportunità di razionalizzarlo, di regolarlo per costruirlo e abitarlo. Forse è questo, oltre la vita, il segreto contenuto nei disegni e nelle pitture di Quinquela Martín: la libertà di sperimentare e di agire, di annodare liberamente l'uomo allo spazio e lo spazio al tempo, come le corde di una barca alle vele e le vele al vento. Ogni immagine che rappresenta questa condizione di libertà, esprime la teoria del vivere e contiene la volontà di rappresentare il mondo nella sua totalità, documentando uomo, spazio e tempo

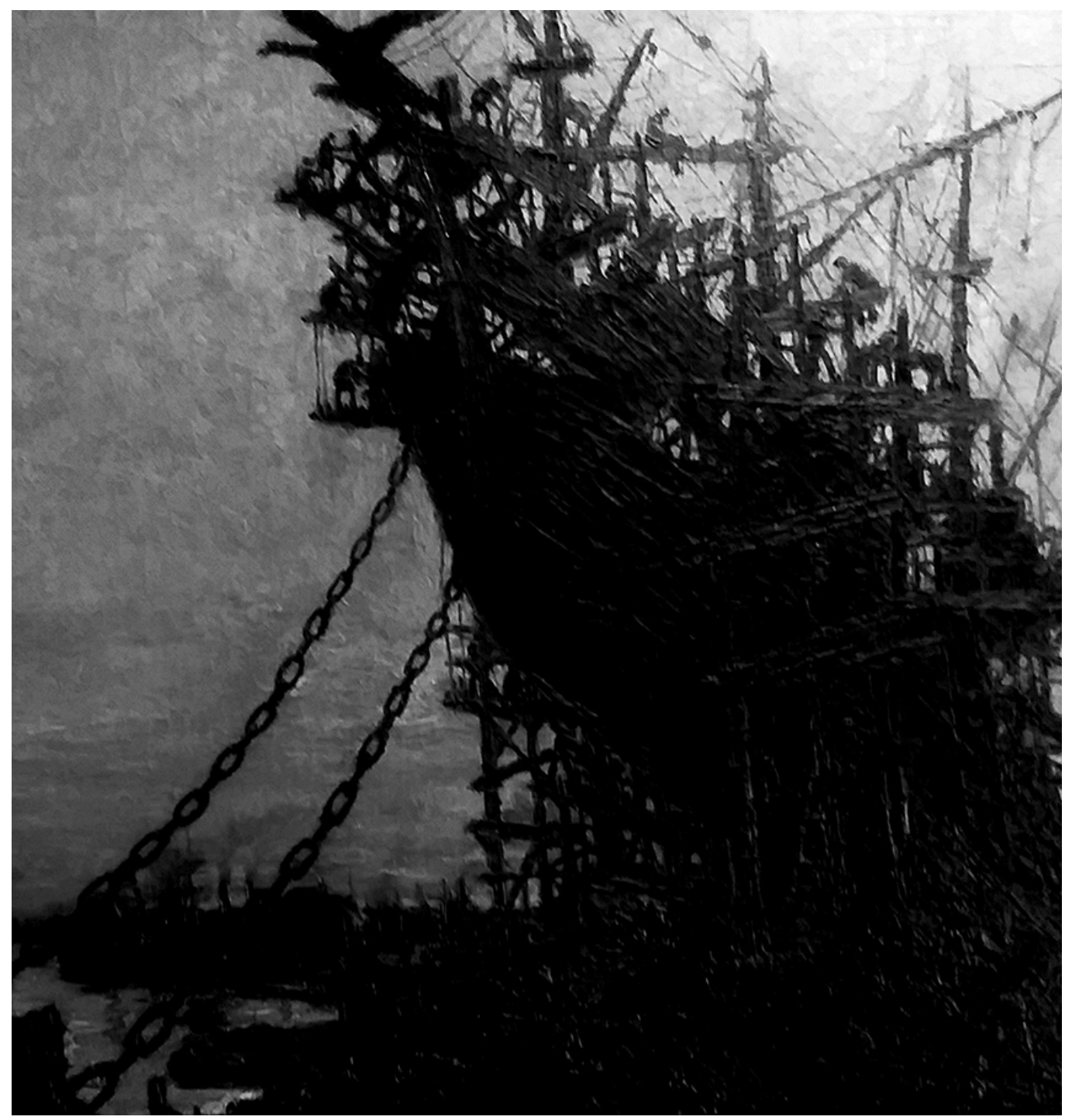


oltre la temporalità dell'esistenza umana.Vedere, scoprire e rappresentare lo spazio vissuto oltre quello fisico, significa comprendere il modo di esistere, il modo di vivere e di abitare il mondo, perché se l'uomo forma e disegna in questo modo il suo spazio, alla fine, in ogni passaggio, lo spazio diventa il disegno di un'emozione, diventa la sua vita.

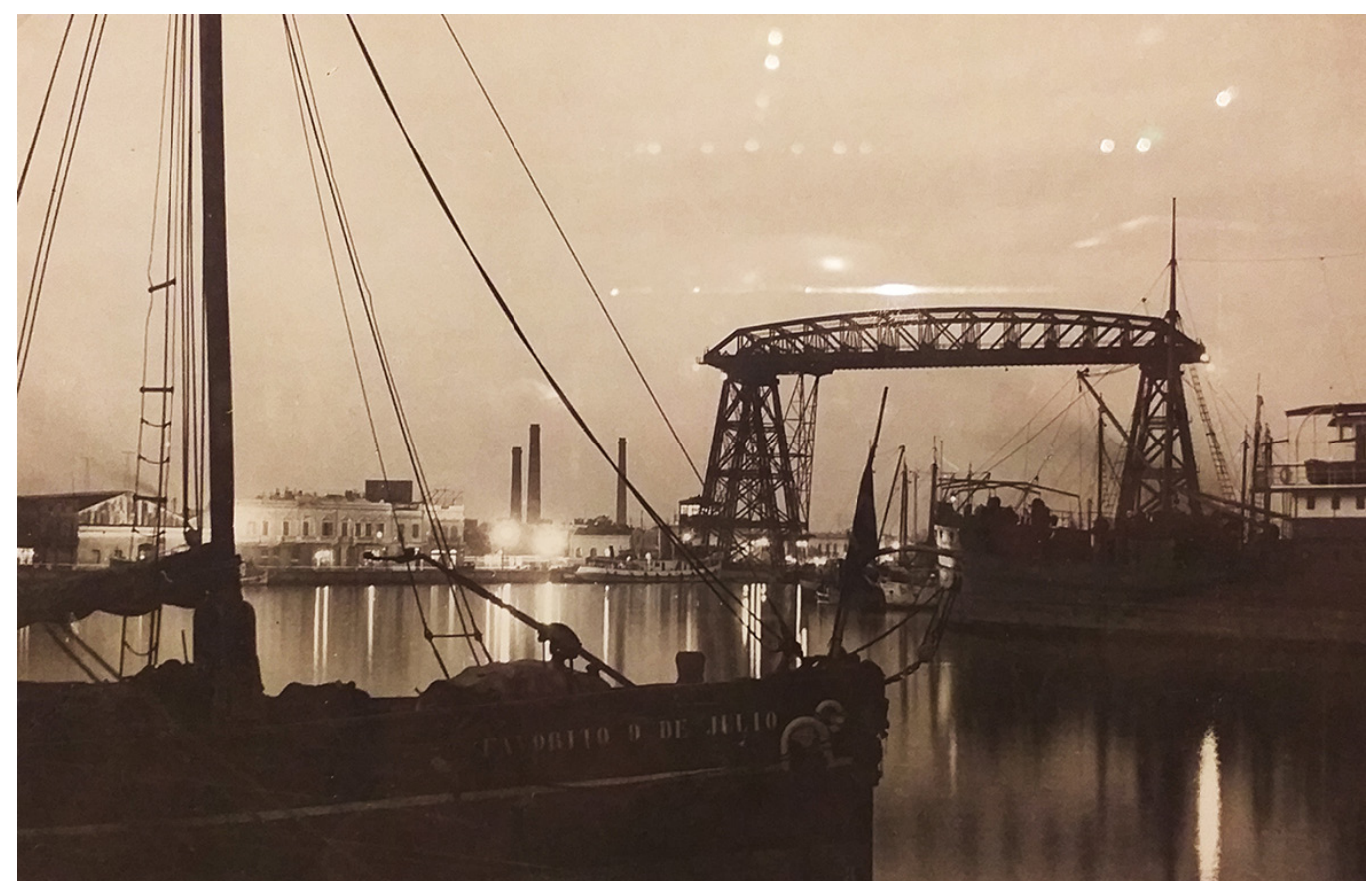

Note

[I] Nadotti Maria 2015, p. 10.

[2] Berger lavorò come insegnante di disegno dai venti ai trenta anni. In quel periodo si legò al Partito Comunista britannico iniziando a scrivere su Tribune sotto la supervisione di George Orwell.

[3] Benito Quinquela Martín, Buenos Aires, 1890-1977. Disegnatore e pittore argentino, principale esponente del gruppo dei Pittori della Boca, tra i quali: Alfredo Lazzari ( I 87 I - 1949), Eugenio Daneri (I 88 I-1970), Miguel Carlos Victorica (1884- I955) Fortunato Lacámera (1887-195 I), Víctor Cúnsolo (I 898-1937), José Desiderio Rosso (1 898- I 958), Miguel Diomede (I 902 1974), José Luis Menghi (1904-1985), Jerónimo Marcos Tiglio (1903-1976).

[4] Si veda: a) Just Imagine, USA, Fox, 1930. Directed by David Butler. Film release 23rd November 1930 in Los Angeles. b) Asphalt, Germany, Universum Film A.G., 1929. Directed by Joe May. Film release I I th March 1929 in Berlin. c) Der letzte Mann, Germany, Union-Film der Ufa, 1924. Directed by Friedrich Wilhelm Plumpe (Murnau).

[5] Molti storici concordano sul fatto che La Boca è il luogo in cui Pedro de Mendoza fondò la città di Santa María de los Buenos Aires, nel 1536.

[6] La Nacion, domingo 8 de diciembre 2019. La Nacion festeja sus primeros I 50 años. LNI 50 Aniversario, p. 36.

[7] Per i molti problemi, come la profondità dell'acqua e i banchi di sabbia, il porto si spostò più a Nord di Buenos Aires.

[8] "La realtà abitativa del barrio de La Boca fu espressa al ritmo dell'immensa ondata immigratoria che giunse a Buenos Aires dopo il | 870. Per rispondere alla grande concentrazione di popolazione, che per motivi di lavoro doveva abitare la zona portuaria si inventò la tipologia architettonica del conventillo, differenziata dalla tipologia presente nei quartieri del centro della città che, invece, si adattava sulla struttura delle antiche case. La particolarità del conventillo de La Boca non stava soltanto nel materiale ma anche nella forma simbolica" che creò il genere del vicinato (Casas de la Boca. De como se vive en un barrio de chapa y madera. Museo Benito Quinquela Martín, Buenos Aires, Argentina. Exposición temporaria).

[9] ¿Qué es un Conventillo? Origin y organizacíon de una construccíon con historia. Museo Benito Quinquela Martín, Buenos Aires, Argentina (nel percorso museale).

[ I 0] ¿Qué es un Conventillo? Origin y organizacion de una construccíon con historia. Museo Benito Quinquela Martín, Buenos Aires, Argentina (nel percorso museale).

[ I I] La urbanización del barrio. Conformación del tejido boquense. Museo Benito Quinquela Martín, Buenos Aires, Argentina (nel percorso museale). 
Fig. 10. Rosario Marrocco II Riachuelo dald Benito Quinquela Mart'́ 2020. Buenos Aires, Argentina.

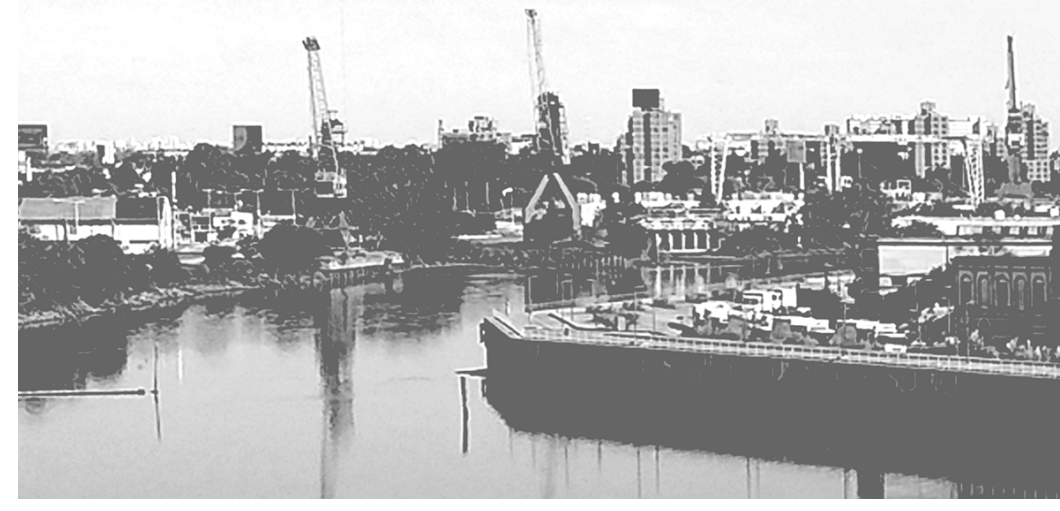

Fig. I I. Rosario Marrocco, La Boca dal terrazzo della casa di Benito Quinquela

Martín, 2020. Buenos Aires, Argentina.
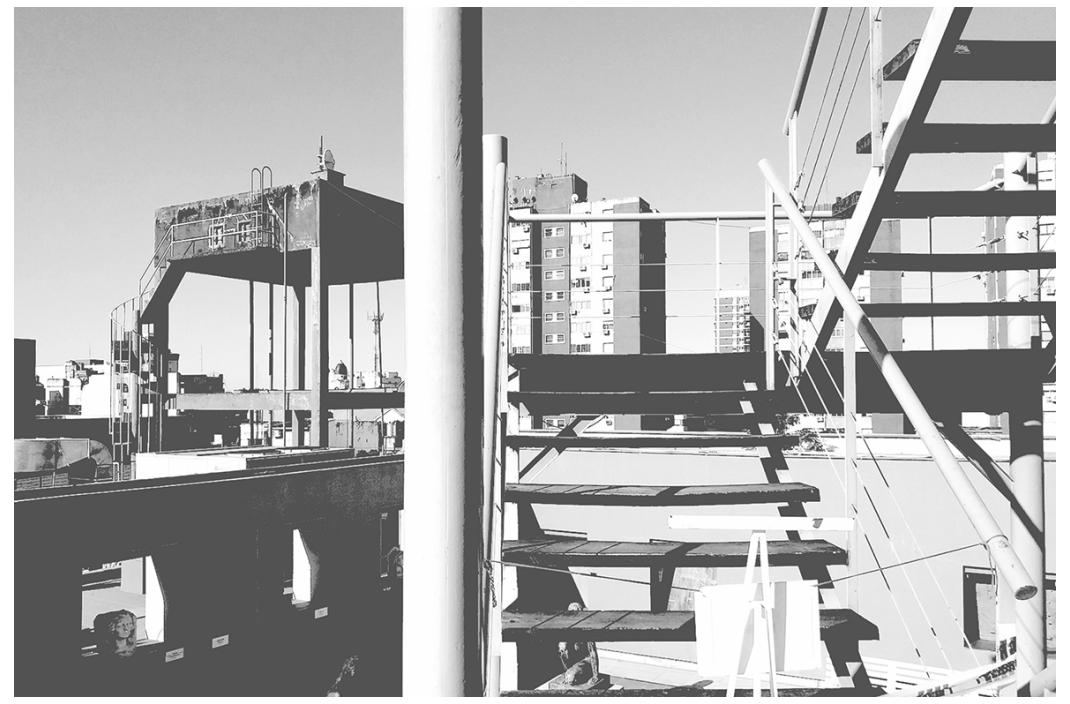

Fig. 12. Rosario Marrocco, La Boca dal terrazzo della

Fundación PROA, 2020.

Buenos Aires, Argentina.

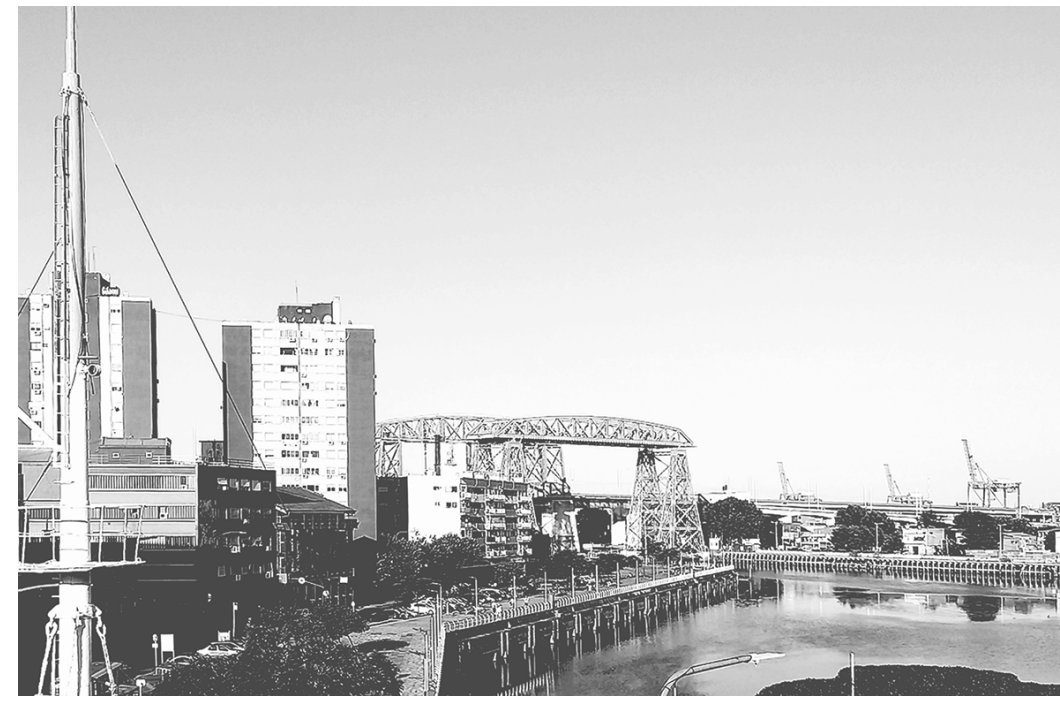




\section{Riferimenti bibliografici}

Adamo Paula, Grau Didi (2009). Quinquela, el pintor de la Boca. El mundo de Quinquela Martín para niños. Buenos Aires: Calibroscopio Ediciones (Colleción pinta tu aldea). Ed. Originale 2017.

Arbolave Graciela, Semino Carlos (2019). La Escuela de Arte de La Boca. Sus maestros. Tigre-Provincia de Buenos Aires: MAT Museo de Arte Tigre - Tigre Municipio.

Babich Silvina, Cuesta Ferrarazzo Andrea (2018). Navegaciones de Artista en el Riachuelo. La Plata: EDULP. Editorial de la Universidad Nacional de La Plata.

Berger John (201 I). Sobre el dibujo. Barcelona: Editorial Gustavo Gill.

Berger John (20 I5). Modi di vedere (a cura di Maria Nadotti). Torino: Bollati Boringhieri.

Berger John (2000). ¿Cómo aparecen las cosas?, o Carta abierta a Marisa. In AA.WV. El Bodegón. Barcelona: Ed. Galaxia Gutenberg.

Calvino Italo (2016). Le città invisibili. Milano: Mondadori. Ed. originale 1972

Caporicci Miraglia Walter (2018). Benito Quinquela Martin. El hombre que fue nosotros. Buenos Aires: Museo de Bellas Artes Benito Quinquela Martin.

Diaz Potenza Sabrina, Valeiras Yamila (2016). Benito Quinquela y la máquina. Buenos Aires: Museo de Bellas Artes Benito Quinquela Martin

Nadotti Maria (20 I5). Dialogato con John Berger. In Berger John. Modi di vedere. Torino: Bollati Boringhieri.

Voldan de Mac Gaul Milada (1996). Rejas de balcones de la Boca. Buenos Aires: Epsilon Editora srl.

Voldan de Mac Gaul Milada (20I I). Antiguas casas de la Boca. Buenos Aires: Editorial Dunken.

Voldan de Mac Gaul Milada (20I4). La Boca y su luz. Buenos Aires: Editorial Dunken.

Autore

Rosario Marrocco, Sapienza Università di Roma, rosario.marrocco@uniromal.it

Per citare questo capitolo: Marrocco Rosario (2020). II disegno e la costruzione dello spazio di vita e delle relazioni. La Boca di Buenos Aires e lo spazio di Benito Quinquela Martín/The drawing and the construction of the space of life and of relationships. La Boca in Buenos Aires and the space of Benito Quinquela Martín. In Arena A., Arena M., Brandolino R.G., Colistra D., Ginex G., Mediati D., Nucifora S., Raffa P. (a cura di). Connettere. Un disegno per annodare e tessere. Atti del $42^{\circ}$ Convegno Internazionale dei Docenti delle Discipline della Rappresentazione/Connectino. Drawing for weaving relationships. Proceedings of the 42th International Conference of Representation Disciplines Teachers. Milano: FrancoAngeli, pp. 3459-3482 


\title{
The Drawing and the Construction of the Space of Life and of Relationships. La Boca in Buenos Aires and the Space of Benito Quinquela Martín
}

\author{
Rosario Marrocco
}

Abstract

This contribution presents a study on the drawing of the space of life of the barrio de La Boca in Buenos Aires through the representations of Benito Quinquela Martín. Representations of great expressive and spatial intensity that condense the drama and hope of the great immigration to South America. A constant reference to the relationship between man and space as a continuous connection of architectural and social, anthropological and cultural spatialities. Drawings that convert the reality of a poor experience into contrasting futuristic visions alternating with emotional and reflective instances, where the dignity of the trabajo appears a harrowing and tormented constant, expression and foundation of the connection between men and space. In the representations of B.Q.M., which are great connection tissues between the human and the spatial, life built on human actions appears and confused between fumes, tie rods, sails and bow of boats. The result of immigration that has come to the South of the American continent, despite the urban and spatial vitality induced by tourism, the municipality and social transformations, the La Boca space is still based on those representations. The colors and the industrial and port conversions still surround a world made of provisionality where the only certainties seem to be those of relationships -today certainly different- between men and between men and space. A peripheral living space, tireless and reversible, tumultuous and Calvinian, where everything seems to be broken down and recomposed through an unceasing drawing of the space of life.

Keywords

drawing of the space of life, drawing of the space of relationships, La Boca Buenos Aires,

Benito Quinquela Martín, John Berger.

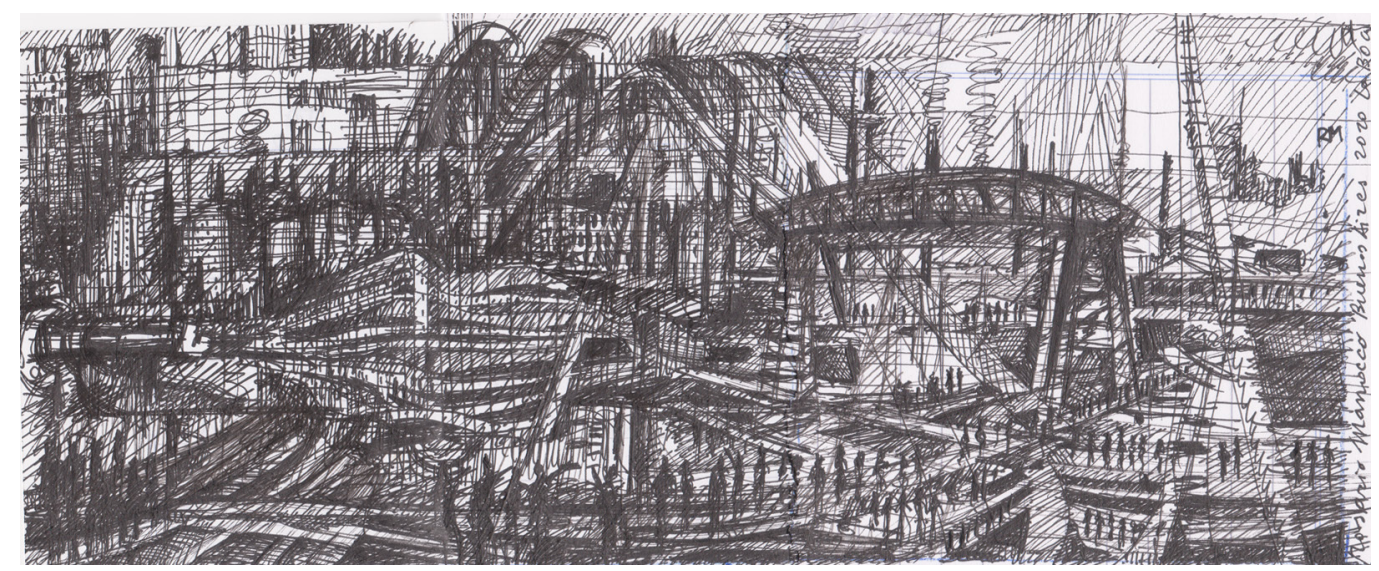


"One always looks at the paintings in the hope of discovering a secret. Not a secret about art, but about life. And if he finds out, it will remain a secret because, after all, it cannot be translated into words. With the words, the only thing that is possible to do is to draw, in broad strokes, a map that guides us towards it"

[Berger 2015, p. 59]

"If I had to enclose in one word the profound tension that marks Berger's work, I would choose a verb: 'to connect'" [I]. Connect everything that is fragmented, separate. All that stratifies over time, by parts, by fragments. Spaces, identities, men. Connecting spaces and men through a common sign and identity, connecting them through a representation. This often happens in the arts, literature, novels, cinematographic narratives, paintings, and when we try to find or find this connection between things, we discover all the relationships between men, the spatial relationships and the relationships between man and space, discovering the space of life and living. We discover the manifestations of life because living is nothing more than a continuous connection between things, which has a beginning and an end.

Indeed, all of Berger's work -even the one dedicated to drawing [Berger 20 II] and the one dedicated to the critical reading of a certain political reality [2]- is aimed at the search for connections, identities and truths, the search for the relationships between seeing the world and being one its part, between representing it and being inside it. On the other hand, if the constant search for the connection between man and space is a priority for the life of man and space, be it physical or mental, all representations, in one way or another, not only express and accompany the search for this condition necessary for survival, but also determine it, fixing the world through its representation. The drawings represent the connection between spaces and men and often contain and express those

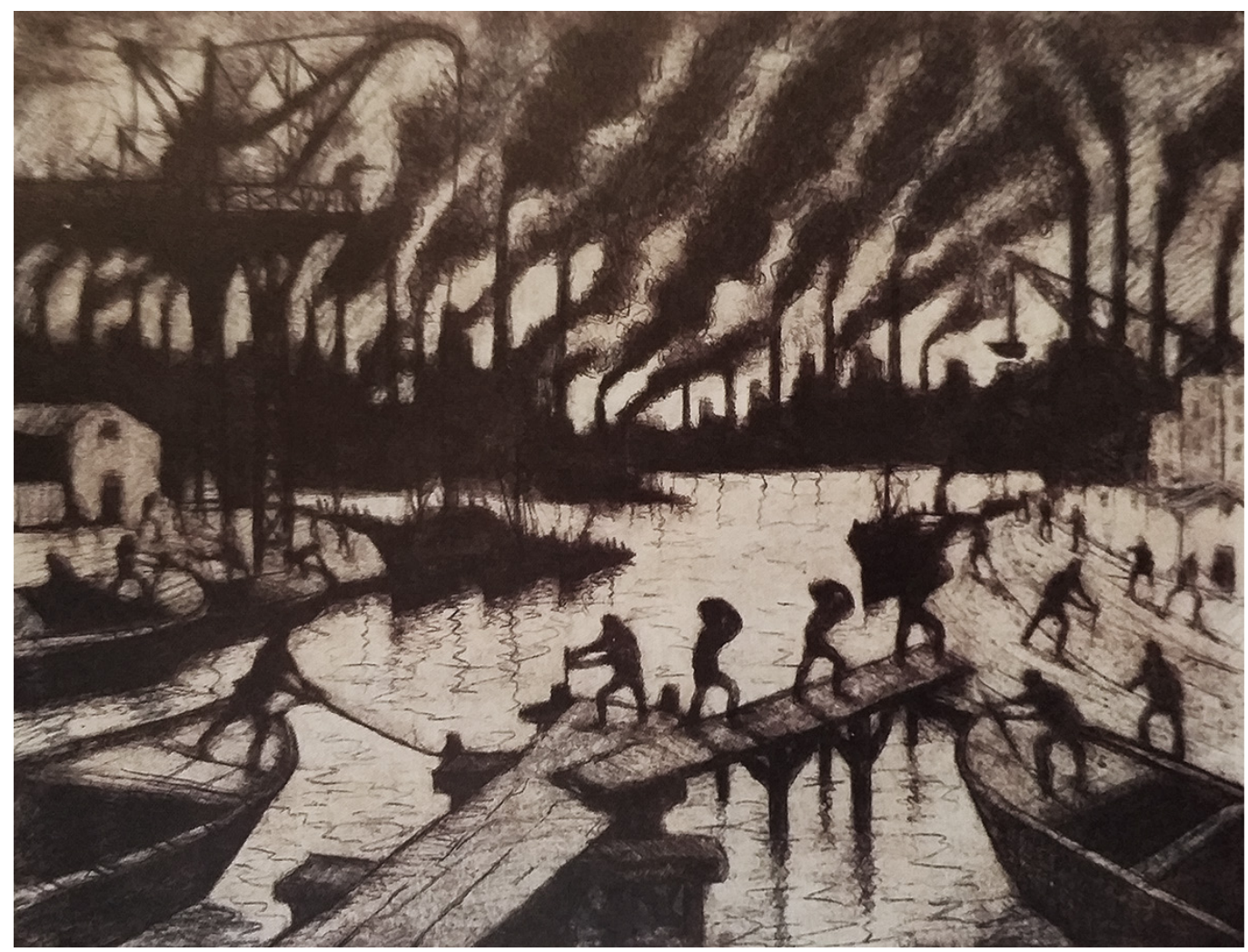




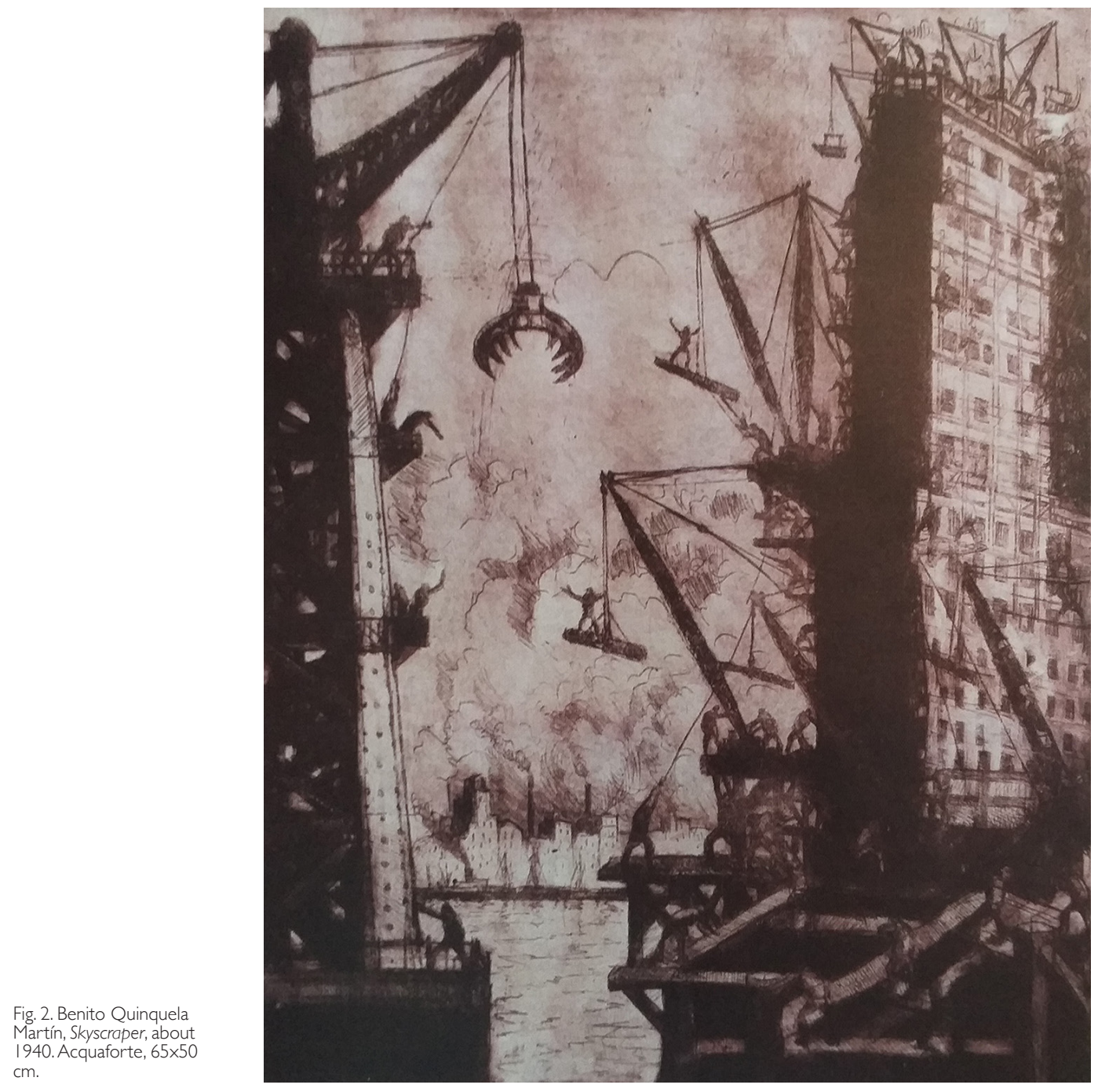

secrets about life and existence in front of which, however, sometimes deep uncertainties remain. Secrets that, as Berger writes, are sought by looking at a drawing. Sometimes they seem to discover and emerge but, inevitably, they then re-knot in the words that try to reveal them and tell them, because in the end, after all, words can only trace directions and visions, compared to those ways of seeing and building the world contained in drawings and representations.

The case of the works of Benito Quinquela Martín [3] represents, in this context, an emblematic case for the constant reference to the relationship between man and space as a continuous connection of architectural and social, anthropological and cultural spatiality. Spatialities represented by his world, his physical space, on the Riachuelo, and his mental space. Representations of great expressive and spatial intensity that summarize and condense the drama and hope of the great immigration to South America. Drawings and representations that convert the reality of a poor experience into contrasting futuristic instances alternating with emotional and reflective visions, where the dignity of the trabajo appears a harrowing and tormented constant, expression and foundation of the connection between men and space. Suffice it to observe the five etchings made around 1940 (figs. I-5) to understand the need to find, build and represent the connection with the world and the relationship with space, always designed through large and complex 


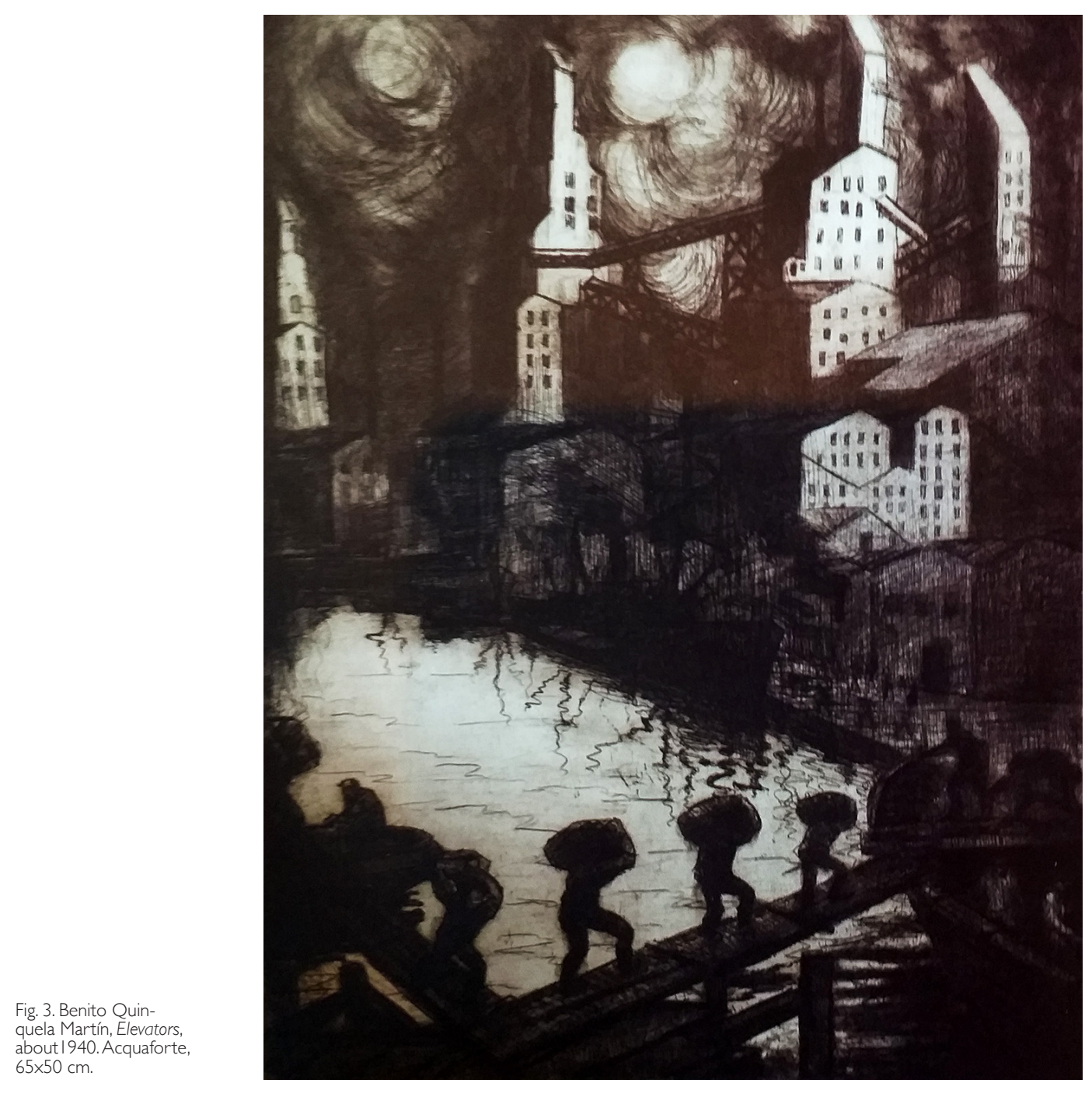

scenographies that seem to evoke the scenarios German and American filmmakers from the various Asphalt, Der letzte Mann or Just Imagine [4]. From time to time in these representations, which are like the great tissues of connection between the human and the spatial, life appears (fig. 6) and, confused between fumes, tie rods, sails and bow of boats, the secret of life built piece by piece on human actions. Secret that unravels and represents itself through an infinite reality, cold and raw, obsessively portrayed, impressed and expressed in every symbolic detail but at the same time didactic and elementary, whose meaning falls and coincides with the will of appropriation bursting out of space. A precise will conducted with confidence through the control of the transformation of space and the relationship with space, but above all through the search for the values of the community and life in common, the human connection between man and man.

Beyond his personal life story -Quinquela Martín was adopted by a Genoese and an indigenous woman- the substratum of his work should be sought precisely in this great historical space [5], La Boca, located south-east of Buenos Aires. The barrio was created by those mainly Italian immigrants, almost all from Genoa, who raised their living space in that empty, hostile and marshy place, with periodic floods and populated only by shacks, reproducing spatial values and human dimensions.

On February 9, 1889, La Nacion reported La aventura de los inmigrantes: "The Italian vapor 


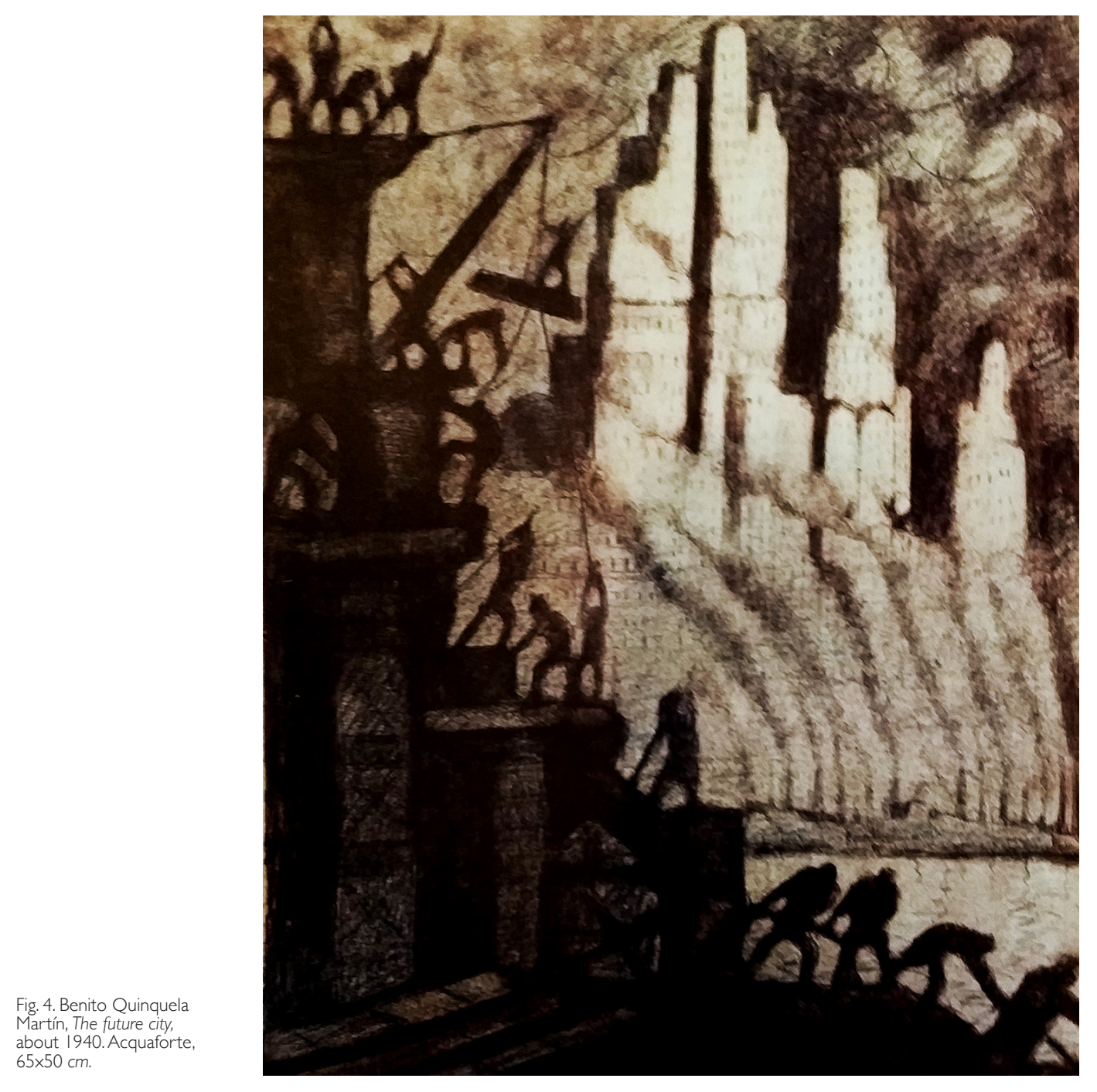

Independente fue sometido a sanitary observation. Los Inmigrantes se incuentran en el lazareto de Martín García" [6]. Part of this impressive immigration stretched on the edge of the Riachuelo, particularly on the mouth (from which, in Spanish, Boca), where its waters flow into the Río de la Plata. A port landscape, for many years the natural port of Buenos Aires, dense with visual and sound verticality resting and embedded on the colored horizon of the Río (fig. 7). A rebounding din of heavy things resting on the water and carried on wooden boards, through ropes, pulleys and nets (figs. I.4). "Cada día de ese puerto era un movimento incesante de barcos; un obrar de talleres, de frigoríficos, de fundiciones; un cargar y descargar de cajones de cereales, de frutas, de carbón; un barullo de gritos, golpes de martillos, sirena de barcos; una vista de grúas, proas, mástiles y cientos de hombres trabajando" [Adamo, Grau 2009, p. 8]. A space in continuous construction, where man, in addition to building, becomes part of the building, because each building bears the exasperated signs of a humanity that frantically seeks its identity in space. "Toda la gente que vivía allí había llegado de Italia y se ayudaban unos a otros, porque sabían que compartiendo lo que tenían y lo que no tenían las tristezas serían menos tristes y las alegrías tendrían más sabor" [Adamo, Grau 2009, p. 8]. 


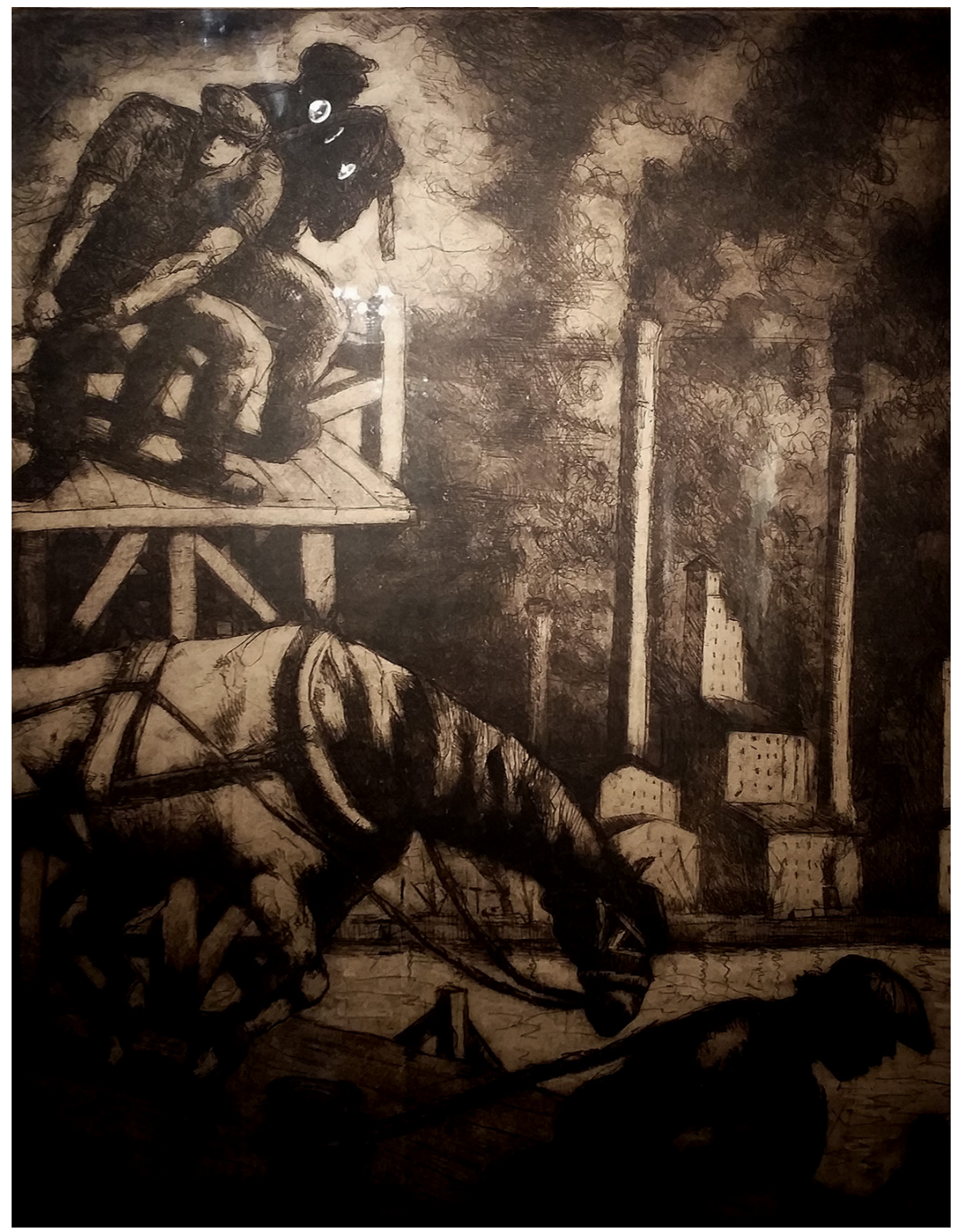

The relationship between men and between men and space, represented by Quinquela Martín, became a determining element for living and living. The space was built on forms of spontaneous and popular coexistence, los conventillos [8], through the use of colored materials obtained from boats and wooden, iron and zinc transport cases. Los conventillos resumed the spontaneous forms of living typical of the peoples of the Mediterranean with the insertion of port construction techniques, with houses raised above pillars, shaped through an overlap of simple volumes of wood and zinc covered with oil pigments typical of boats. So the spaces "de madera y zinc", even before being houses, they retained the identity, shape and matter of those floating boats anchored on the port as places of passage between the old and the new world (fig. 8). Temporary spaces, transitional spaces, resting on the brown Río and inside a gray and black landscape of coal, more black"de las bolsas de carbón" [Adamo, Grau 2009 p. 8].

The drawings and images of this space represent human relationships based on language and living, on social communication and collective living. They represent a spontaneous network of connections between man and space, between man and the landscape in which he finds himself. An extraordinary narration of being able to live and knowing how to live in space, drawing from it all the spontaneous, natural and artificial components it presents, converting them back into their own existence. When Horacio Coppola, in 
Fig. 6. Benito Quinquela Martín, Cold in the recove about 1967. Acquaforte, I 25x $105 \mathrm{~cm}$. (Colleción Museo Benito Quinquela Martín, Buenos Aires, Argentina).

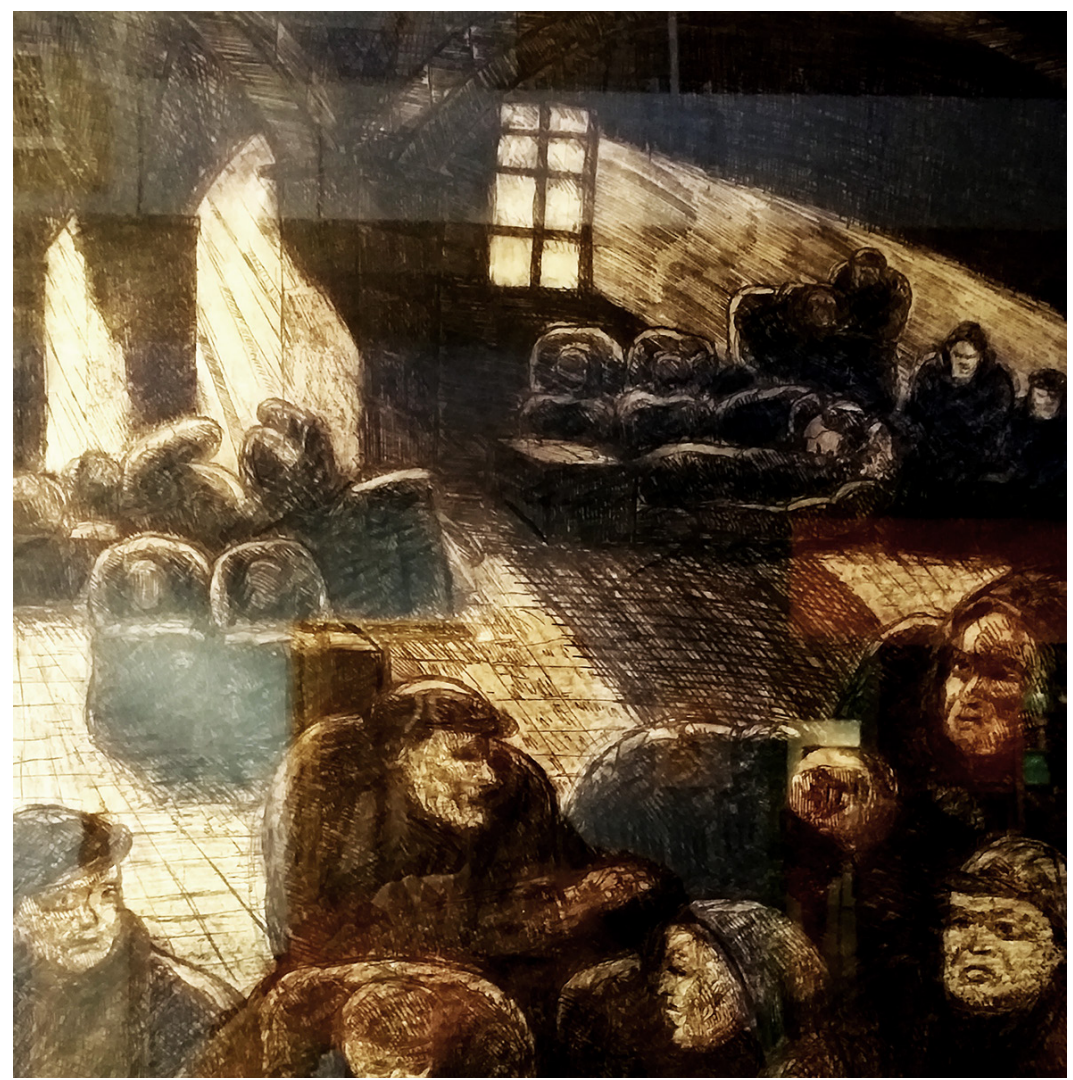

1931, took the Riachuelo, Puente Almirante Brown, in his photo shoot (fig. 9), the landscape he presented was exactly the one designed by Quinquela Martín, weighed down by the brown of the jelly de plata: water, reflections, ropes, iron and smokestacks, with the background of the imposing footprint of the Puente Transbordador Nicolás Avellaneda, inaugurated in 1914. A landscape that still today, after ninety years, remains indelible despite the heavy urban interventions of the viviendas of the seventies and eighties (figs. 10-12). The domestic living spaces welcomed whole families who shared the kitchen, above, and the bathroom, below. The central core inside, like a patio that became the heart of the living space, amplified "y delimitados por galerías abiertas y conectadas desde la planta baja hasta la planta alta mediante escaleras de madera, frequentemente de dos tramos y notablemente empinadas" [9]. The steep stairs, almost like climbing on ropes in ships, belong to that metaphor of connection, of connection between spaces, between things and between people. Life and the secrets of life's relationships are represented as a scenic fiction, from the theatrical aspect, as provisional, because in the poor and concrete reality of a barrio of immigrants, the real secrets to be hidden are instability, temporary and precariousness. For this reason, and in the face of all this, man seeks stability in human relations and with the world, the external one, the floating one, dark and made of water, the port one in Riachuelo.

Despite the urban and spatial vitality induced by tourism, the municipality and social transformations, the La Boca space is still based on these representations. The colors and industrial and port conversions still surround a world made of provisionality where the only certainties really seem to be those of relationships -today certainly differentbetween men and between men and space. Provisionality and uncertainties that reveal themselves in space, which form space. A peripheral living space, tireless and reversible, 
tumultuous and Calvinian, because everything seems to be broken up and recomposed and everything "instead of rising above, hangs below: rope ladders, hammocks, sacked houses, hangers, terraces like ships, water bottles, gas spouts, rotisseries, baskets hanging on twine, freight elevators, showers, trapezes and rings for games, cableways, chandeliers, vases with plants with hanging foliage" [Calvino 201 6, p. 108]. A living space represented in Quinquela Martín's drawings and paintings and in Coppola's photographic shots as well as, in the same way, is represented on the walls of the barrio, on people's faces and on their shirts, in the perspectives of the galleries and courtyards still visible, in the sounds, incessant and continuous, composed of sounds and words. Everything is an incredible design of a living space and a life constantly lived in space. Everything is a great and real representation of relationships. "Starting from living together and communicating on the patio of the conventillo, the inhabitant of La Boca designed his social conscience with a strong accent on solidarity, an attitude provoked by the workers' domination of the family, by the high demand compared to the lack of services and by the crowding and the condition of hygiene of the places. Thus, these precarious conditions of life were compensated with a fraternal conscience and solidarity" [10]. An immense drawing in progress of human abilities to connect, weave and build the world. In full compositional and constructive freedom, the design of La Boca "se caracterizó por la ausencia de todo tipo de regulacíon que afectara esta generación espontánea de las viviendas, de manera que no existió ningún criterio de orden compositivo ni tampoco una fijación de alineaciones para las fachadas y las alturas de las casas. Así fue que la voluntad de dotar a Buenos Aires de una aparencia ordenada, no encontró lugar este barrio" [II].

Going back to Berger's thought, the vision of the secret of life in a representation seems to be broken down here, because the secret of representation coincides with the represented: life is the secret revealed in the represented life. Beyond any aesthetic or typologi-

Fig. 7. Benito Quinquela Martín, Los dos amigos, 1960. Olio on the table, $121 \times 121 \mathrm{~cm}$. (Colleción Museo Benito Quinquela Martín, Buenos Aires,

Argentina).

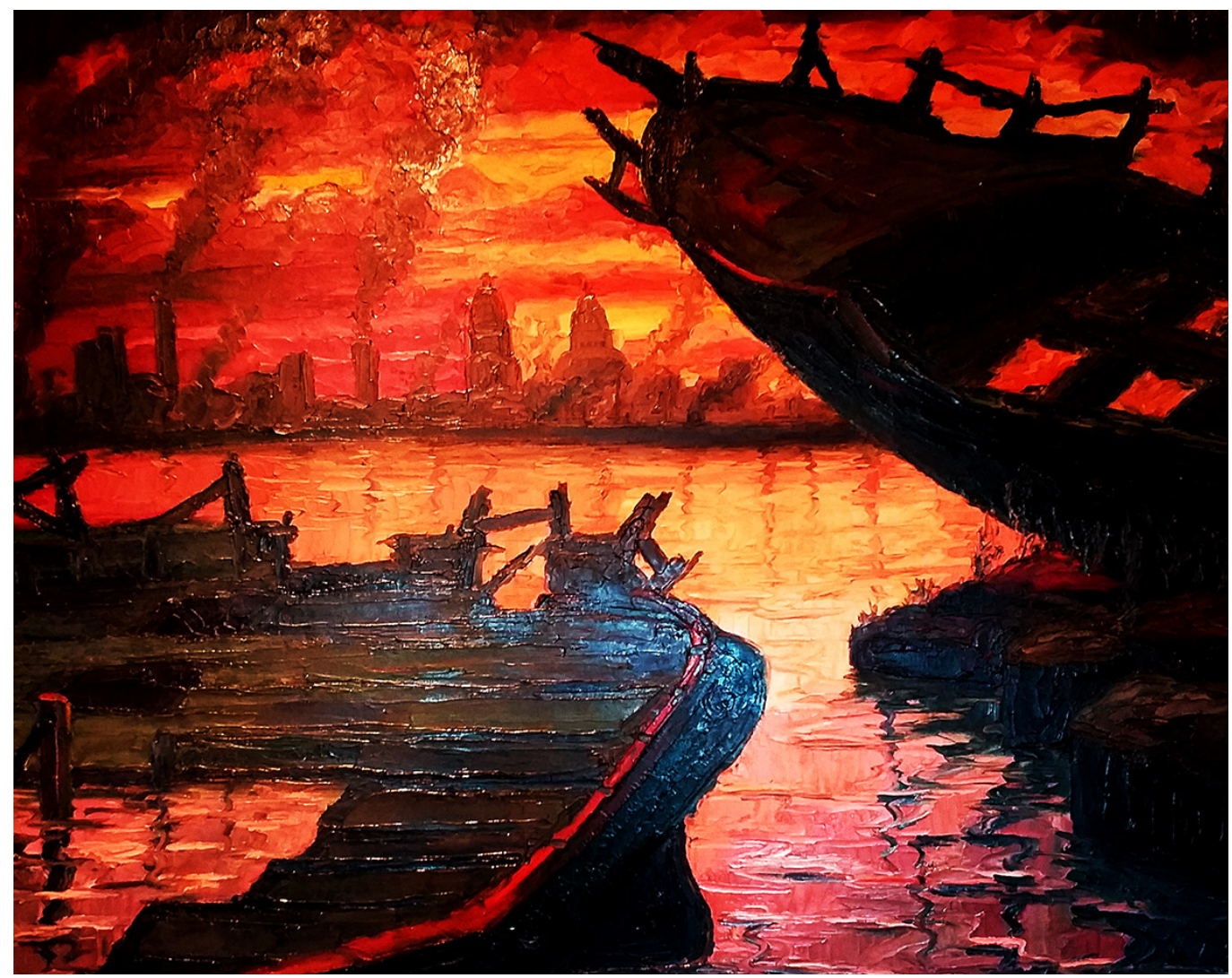


cal value, the drawings (figs. I-5, 7,9 ) represent the social value of space also through the return to that basic human condition where working, producing and acting define the social reasons for human existence in space and support permanence on earth through the human moral capacity to exist and work ethically. In this relationship between man and space also time, as a measure of life, becomes an essential phenomenon, corresponding to the speed of acting in a pulsating and living organic space. A physical space, container of connections and relationships, crossed by human and immaterial visions and perceptions that convert it into a mental space. The need and need to create the living space through life in space often confronts and contrasts with the opportunity to rationalize it, to regulate it to build and inhabit it. Perhaps this is, beyond life, the secret contained in Quinquela Martín's drawings and paintings: the freedom to experiment and act, to freely tie man to space and space to time, like the ropes of a sailboat and the sails in the wind. Each image that represents this condition of freedom, expresses the theory of living and contains the will to represent the world as a whole, documenting man, space and time beyond the temporality of human existence. Seeing, discovering and representing the space lived beyond the physical space, means understanding the way of existing, the way of living and living in the world, because if man forms and draw his space in this way, in the end, in every passage, space becomes the drawing of an emotion, it becomes his life.

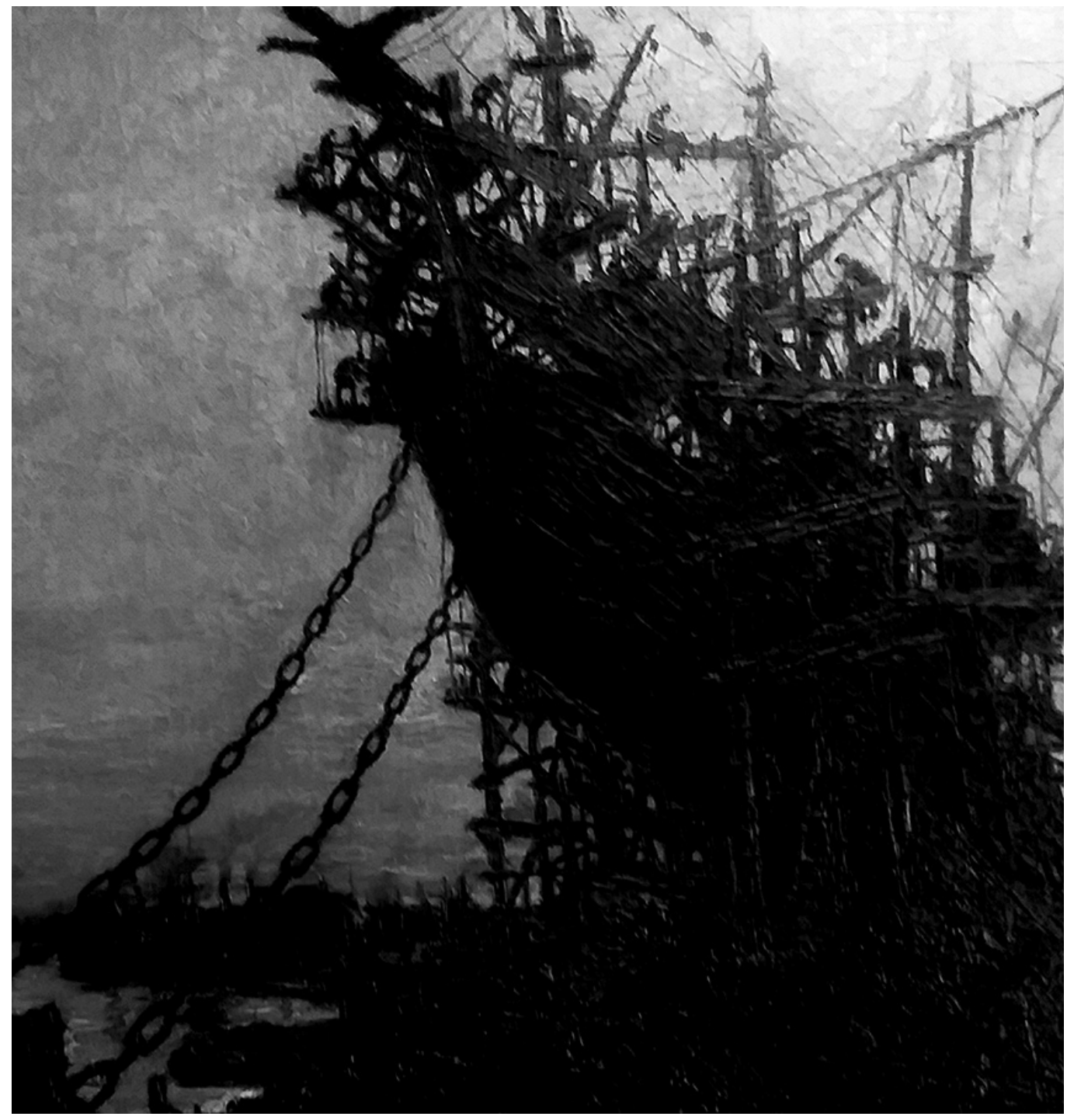


Fig. 9. Horacio Coppola, Riachuelo. Almirante Brow Bridge, 1931. Gelatina de plata. Stampa d'epoca. Jean-Louis Larivière Collection

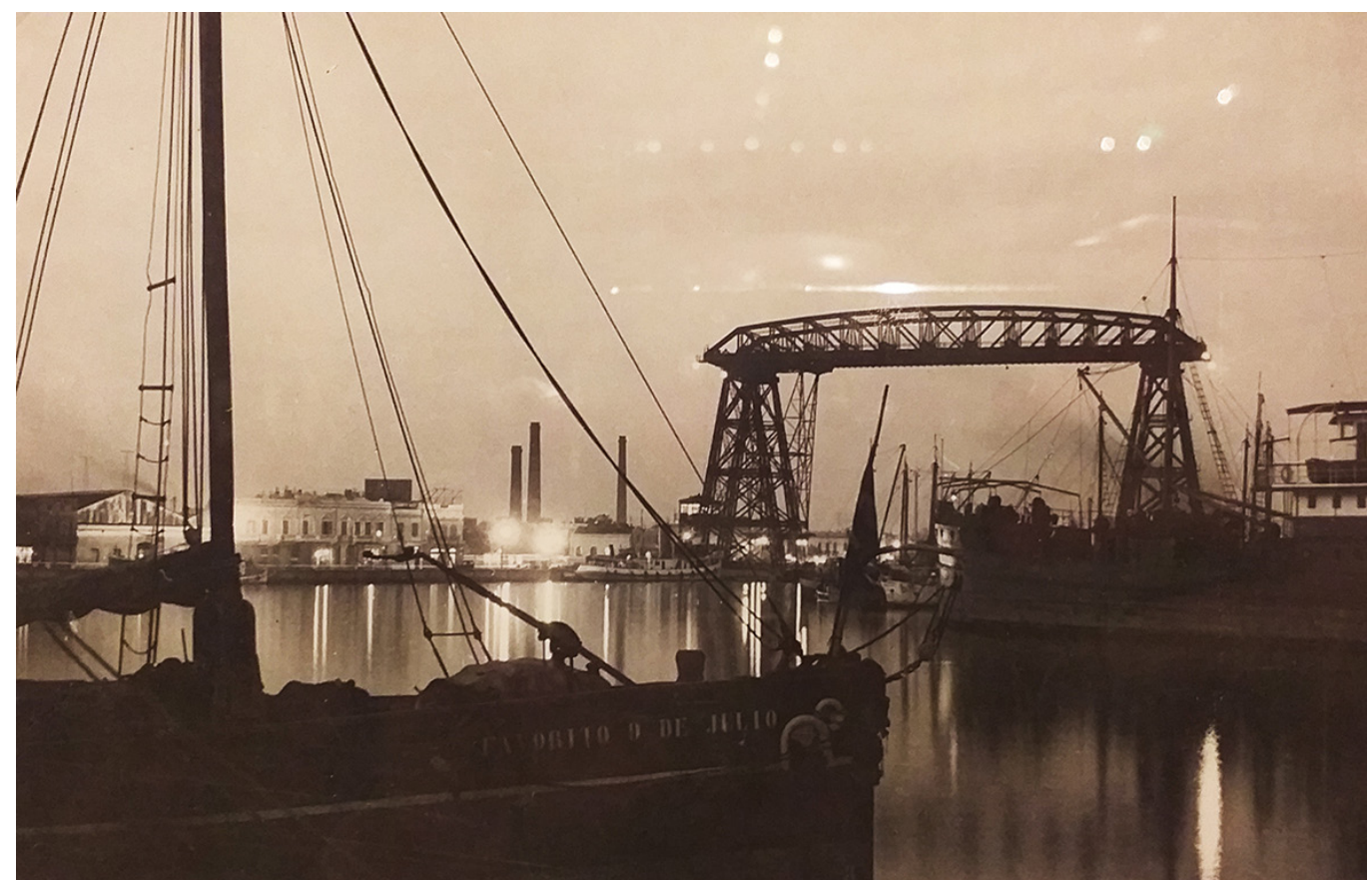

Notes

[I] Nadotti Maria 2015, p. 10.

[2] Berger worked as a drawing teacher from twenty to thirty years old. At that time he joined the British Communist Party and started writing in Tribune under the supervision of George Orwell.

[3] Benito Quinquela Martín, Buenos Aires, 1890-1977, argentine painter, principal exponent of the Boca Painters group including: Alfredo Lazzari (187|-1949), Eugenio Daneri (I88|-1970), Miguel Carlos Victorica (1884-1955), Fortunato Lacámera (| 887-195|),Víctor Cúnsolo (1898-1937), José Desiderio Rosso (1898-1958), Miguel Diomede (1902-1974), José Luis Menghi (1904-1985), Jerónimo Marcos Tiglio (1903-1976).

[4] See: a) Just Imagine, USA, Fox, 1930. Directed by David Butler. Film release 23rd November 1930 in Los Angeles. b) Asphalt, Germany, Universum Film A.G., 1929. Directed by Joe May. Film release I I th March 1929 in Berlin. c) Der letzte Mann, Germany, Union-Film der Ufa, 1924. Directed by Friedrich Wilhelm Plumpe (Murnau).

[5] Many historians agree that La Boca is the place where Pedro de Mendoza founded the city of Santa María de los Buenos Aires in 1536.

[6] La Nacion, Sunday December 8, 20I9. La Nacion celebrates its first I50 years. LNI 50 Aniversario, p. 36.

[7] For many problems, such as the depth of the water and the sandbanks, the port moved further north than Buenos Aires.

[8] "The living reality of the barrio of La Boca was expressed at the rate of the immense immigration wave that reached Buenos Aires after 1870.To respond to the large concentration of population, which for work reasons had to live in the port area, the architectural typology was invented of the conventillo, differentiated by the typology present in the neighborhoods of the city center which, instead, adapted to the structure of the ancient houses. The particularity of the conventillo de la Boca was not only in the material but also in the symbolic form" which created the genre of the neighbourhood (Houses of La Boca. How you live in a chapa y madera neighborhood. Benito Quinquela Martín Museum, Buenos Aires, Argentina. Temporary exposure).

[9] What is a Conventillo? Origin and organization of a construction with history. Benito Quinquela Martín Museum, Buenos Aires, Argentina (in the museum itinerary).

[10] What is a Conventillo? Origin and organization of a construction with history. Benito Quinquela Martín Museum, Buenos Aires, Argentina (in the museum itinerary).

[I I] The urbanization of the neighborhood. Conformation of the boquense tissue. Benito Quinquela Martín Museum, Buenos Aires, Argentina (in the museum itinerary). 
Fig. 10. Rosario Marrocco, The Riachuelo from the home of Benito Quinquela Martín, 2020. Buenos Aires, Argentina

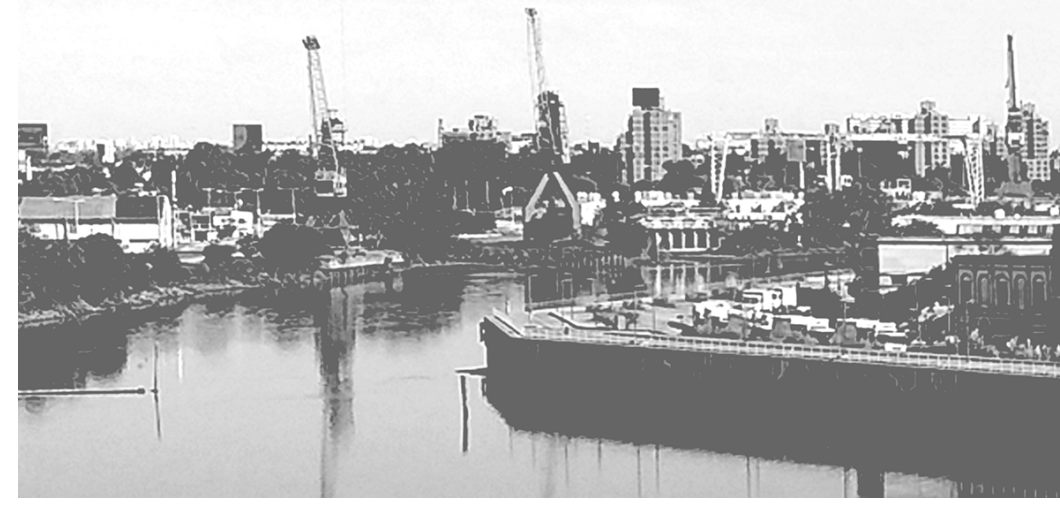

Fig I I. Rosario Marrocco, La Boca from the terrace of the house of Benito
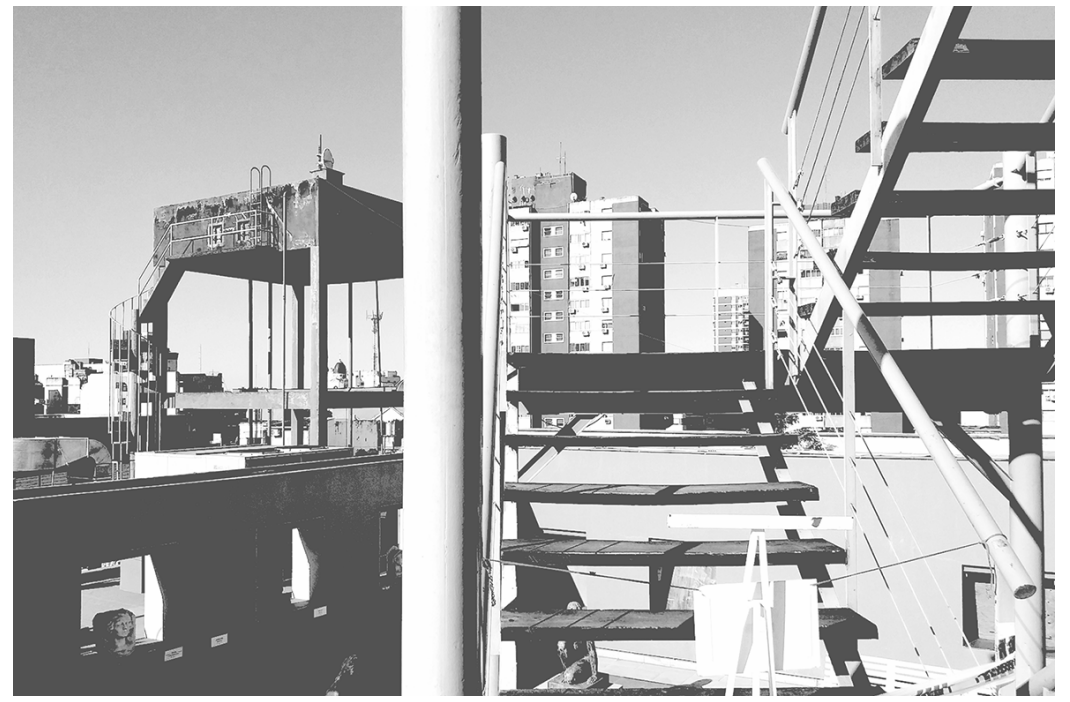

Fig. 12. Rosario Marrocco, La Boca from the terrace of the Fundación PROA,

2020. Buenos Aires, Argentina.

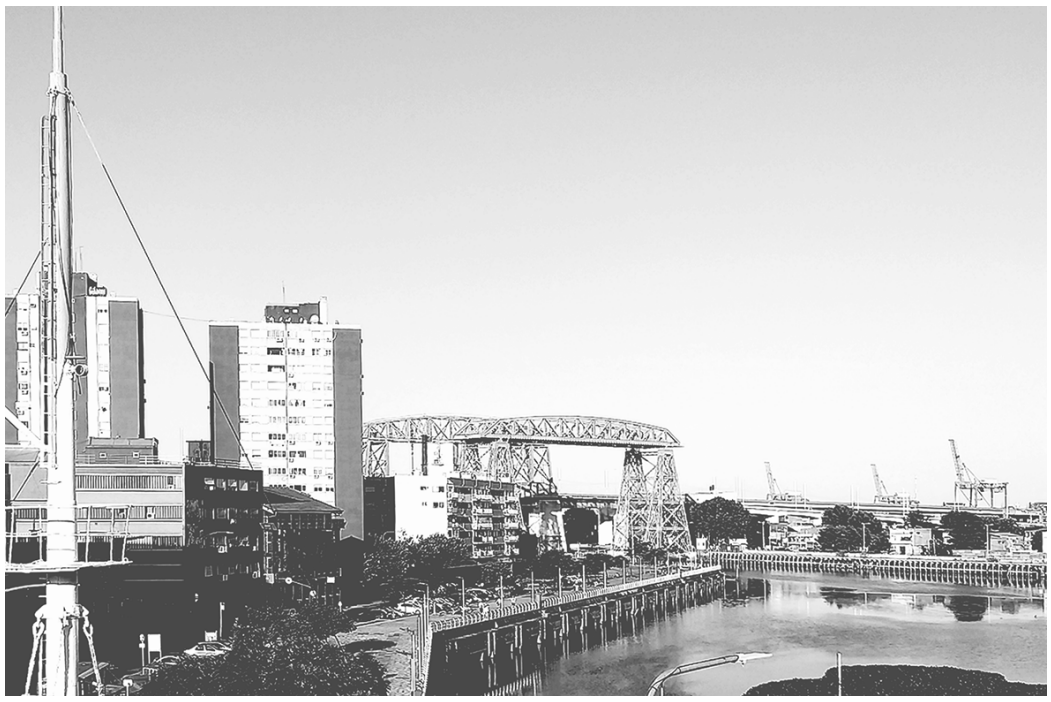




\section{References}

Adamo Paula, Grau Didi (2009). Quinquela, el pintor de la Boca. El mundo de Quinquela Martín para niños. Buenos Aires: Calibroscopio Ediciones (Colleción pinta tu aldea). Ed. Originale 2017.

Arbolave Graciela, Semino Carlos (2019). La Escuela de Arte de La Boca. Sus maestros. Tigre-Provincia de Buenos Aires: MAT Museo de Arte Tigre - Tigre Municipio.

Babich Silvina, Cuesta Ferrarazzo Andrea (2018). Navegaciones de Artista en el Riachuelo. La Plata: EDULP. Editorial de la Universidad Nacional de La Plata.

Berger John (201 I). Sobre el dibujo. Barcelona: Editorial Gustavo Gill.

Berger John (20 I5). Modi di vedere (a cura di Maria Nadotti). Torino: Bollati Boringhieri.

Berger John (2000). ¿Cómo aparecen las cosas?, o Carta abierta a Marisa. In AA.WV. El Bodegón. Barcelona: Ed. Galaxia Gutenberg.

Calvino Italo (2016). Le città invisibili. Milano: Mondadori. Ed. originale 1972

Caporicci Miraglia Walter (2018). Benito Quinquela Martin. El hombre que fue nosotros. Buenos Aires: Museo de Bellas Artes Benito Quinquela Martin.

Diaz Potenza Sabrina, Valeiras Yamila (2016). Benito Quinquela y la máquina. Buenos Aires: Museo de Bellas Artes Benito Quinquela Martin

Nadotti Maria (20 I5). Dialogato con John Berger. In Berger John. Modi di vedere. Torino: Bollati Boringhieri.

Voldan de Mac Gaul Milada (1996). Rejas de balcones de la Boca. Buenos Aires: Epsilon Editora srl.

Voldan de Mac Gaul Milada (20I I). Antiguas casas de la Boca. Buenos Aires: Editorial Dunken.

Voldan de Mac Gaul Milada (20I4). La Boca y su luz. Buenos Aires: Editorial Dunken.

\section{Author}

Rosario Marrocco, Sapienza Università di Roma, rosario.marrocco@uniromal.it

To cite this chapter. Marrocco Rosario (2020). Il disegno e la costruzione dello spazio di vita e delle relazioni. La Boca di Buenos Aires e lo spazio di Benito Quinquela Martín/The drawing and the construction of the space of life and of relationships. La Boca in Buenos Aires and the space of Benito Quinquela Martín. In Arena A., Arena M., Brandolino R.G., Colistra D., Ginex G., Mediati D., Nucifora S., Raffa P. (a cura di). Connettere Un disegno per annodare e tessere. Atti del $42^{\circ}$ Convegno Internazionale dei Docenti delle Discipline della Rappresentazione/Connecting. Drawing for weaving relationships. Proceedings of the 42th International Conference of Representation Disciplines Teachers. Milano: FrancoAngeli, pp. $3459-3482$. 